\title{
mütefekkir
}

Aksaray Üniversitesi İslami Illimler Fakültesi Dergisi

cilt / volume: 8 - sayı / issue: $15 \bullet$ haziran / june 2021 • 243-262

ISSN: 2148-5631 • e-ISSN: 2148-8134・DOI: 10.30523/mutefekkir.939298

الفخر النرجسي في الشعر الجاهلي (دراسة أسلوبية نقدية)

Câhiliye Şiirinde Narsisist Gurur (Eleștirel Usul Çalışması)

Narcissistic Pride in Pre-Islamic Poetry (Critical Usul/Method Study)

\section{Bozan ALHAMAD}

Dr. Öğr. Üyesi, Aksaray Üniversitesi İslami İlimler Fakültesi Temel İslam Bilimleri

Bölümü Arap Dili ve Belagatı Anabilim Dalı, Aksaray, Türkiye

Assist. Prof., Aksaray University Faculty of Islamic Education Department of Basic Islamic

Sciences Department of Arabic Language and Rhetorics, Aksaray, Turkey

bozan555@hotmail.com | https://orcid.org/0000-0001-8446-8505

(1) Makale Bilgisi / Article Information:

Makale Türü / Article Type: Araştırma Makalesi / Research Article

Geliş Tarihi / Received: 13.07.2020

Kabul Tarihi / Accepted: 05.02.2021

Yayın Tarihi / Published: 15.06.2021

9 Atıf / Cite as: Alhamad, Bozan. "Câhiliye Şiirinde Narsisist Gurur (Eleştirel Usul Çalışması)". Mütefekkir 8/15 (2021), 243-262. https://doi.org/10.30523/mutefekkir.939298

(C) Telif / Copyright: Published by Aksaray Üniversitesi İslami İlimler Fakültesi / Aksaray University Faculty of Islamic Education, 68100, Aksaray, Turkey. Tüm Hakları saklıdır / All rights reserved.

约 İntihal / Plagiarism: Bu çalışma hakem değerlendirmesinden geçmiş, bir intihal yazılımı ile taranmıştır. İntihal yapılmadığı tespit edilmiştir. This article has gone through a peer review process and scanned via a plagiarism software. No plagiarism has been detected. 
الفخر النرجسي في الشعر الجاهلي (دراسة أسلوبية نقدية)

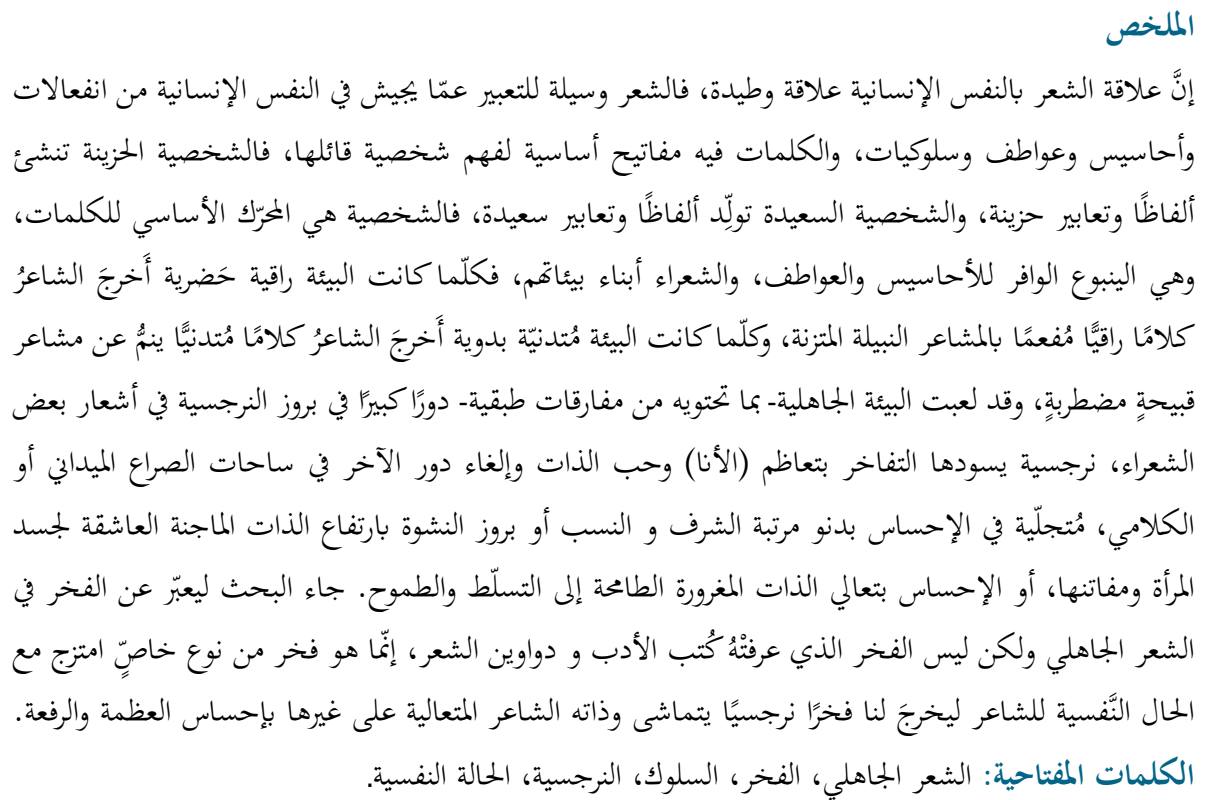

\section{Câhiliye Şiirinde Narsisist Gurur (Eleștirel Usul Çalışması)}

Öz

Şiirin insan ruhuyla ilişkisi yakın bir ilişkidir, bu nedenle şiir insan ruhunda kaynayan hisleri, gel-gitleri, duyguları ve davranışları ifade etmenin bir yoludur. Şiirde geçen kelimeler şairin kişiliğini anlamak için temel anahtarlardır. Öyle ki hazin şahsiyet hüzünlü lafızlar ve tabirler oluştururken mutlu şahsiyet mutlu lafızlar ve tabirler meydana getirir. Çünkü şahsiyet kelimeler için ana motor olduğu gibi duygu ve hisler için bereketli bir kaynaktır. Şairler yaşadıkları çevrenin çocuklarıdır ve çevre ne kadar zarif ve medeni olursa şair de dengeli, asil duygularla dolu söz ortaya koyar. Yine bu çevre ne kadar kalitesiz, yabani olursa şair de kötü ve zararlı duyguları yansıtan kalitesiz söz ortaya koyar. İslâm öncesi dönemindeki çevre, içerdiği sınıf farklılıkları sebebiyle bazı şairlerin şiirlerinde narsizmin ortaya çıkmasında büyük rol oynamıştır. Sözlü ya da yüz yüze mücadele alanlarında ego, kendini beğenmişlik, övünme ve diğerinin rolünü ortadan kaldırma, soy ve şeref mertebesi gözetmeksizin veyahut kadının bedenine ve onun cazibesine aşık, kendine kızan benliğin yükselişiyle coşkuyu ortaya çıkararak veya otoriterlik ve hırs peşinde olan kibirli bir benliğin aşkınlığı duygularıyla narsizmi ön plana çıkartır. Bu araştırma Câhiliye şiirindeki gururu ifade etmek için ortaya kondu. Ancak söz konusu bu gurur edebiyat kitaplarının ve şiir divanlarının tanımladığı gurur değildir. Daha ziyade, şairin aşkın benliğini başkalarına göre bir ihtişam ve yüce duygusuyla eşleştiren narsisist bir gururu bizim önümüze koyması için şairin psikolojik durumuyla birleștirilmiş özel bir türden gururdur.

Anahtar Kelimeler: Câhiliye Şiiri, Gurur, Davranış, Narsisizm, Psikolojik Durum. 


\title{
Narcissistic Pride in Pre-Islamic Poetry (Critical Usul/Method Study)
}

\begin{abstract}
The relationship of poetry with the human soul is a close one, poetry is a means of expressing the emotions, feelings, behaviors that are simmering in the human soul, and words contain essential keys to understanding the personality of the one who says it. The sad personality creates sad words and expressions, and the happy personality generates happy words and expressions, the personality is the main source of the words. It is the abundant fountain of feelings and emotions. Poets are the sons of their environments, so the more sophisticated and cultured their environment is, the more it will produce poets full of noble and balanced feelings. Whenever the environment is Bedouin and low in quality the poets are going to use a lowly speech that expresses ugly and troubling feelings. The pre-Islamic environment - with its class paradoxes - has played a major role in the emergence of narcissism in the poetry of some poets. It is a narcissism that is dominated by boasting about ego and self-love and the elimination of the role of the other, narcissism characterized by a sense of low honor and lineage, or it is characterized by the greatness of lineage, honor, and authority. This study aims to express pride in pre-Islamic poetry; however, it does not mean the pride that was mentioned in literature books and poetry collections, rather it aims to clarify the pride that is of a special kind. The pride that mixes with the psychological state of the poet and emerged to us as narcissistic pride shows the same poet with a sense of grandeur and sublime.
\end{abstract}

Keywords: Pre-Islamic poetry, pride, behavior, narcissism, psychological state.

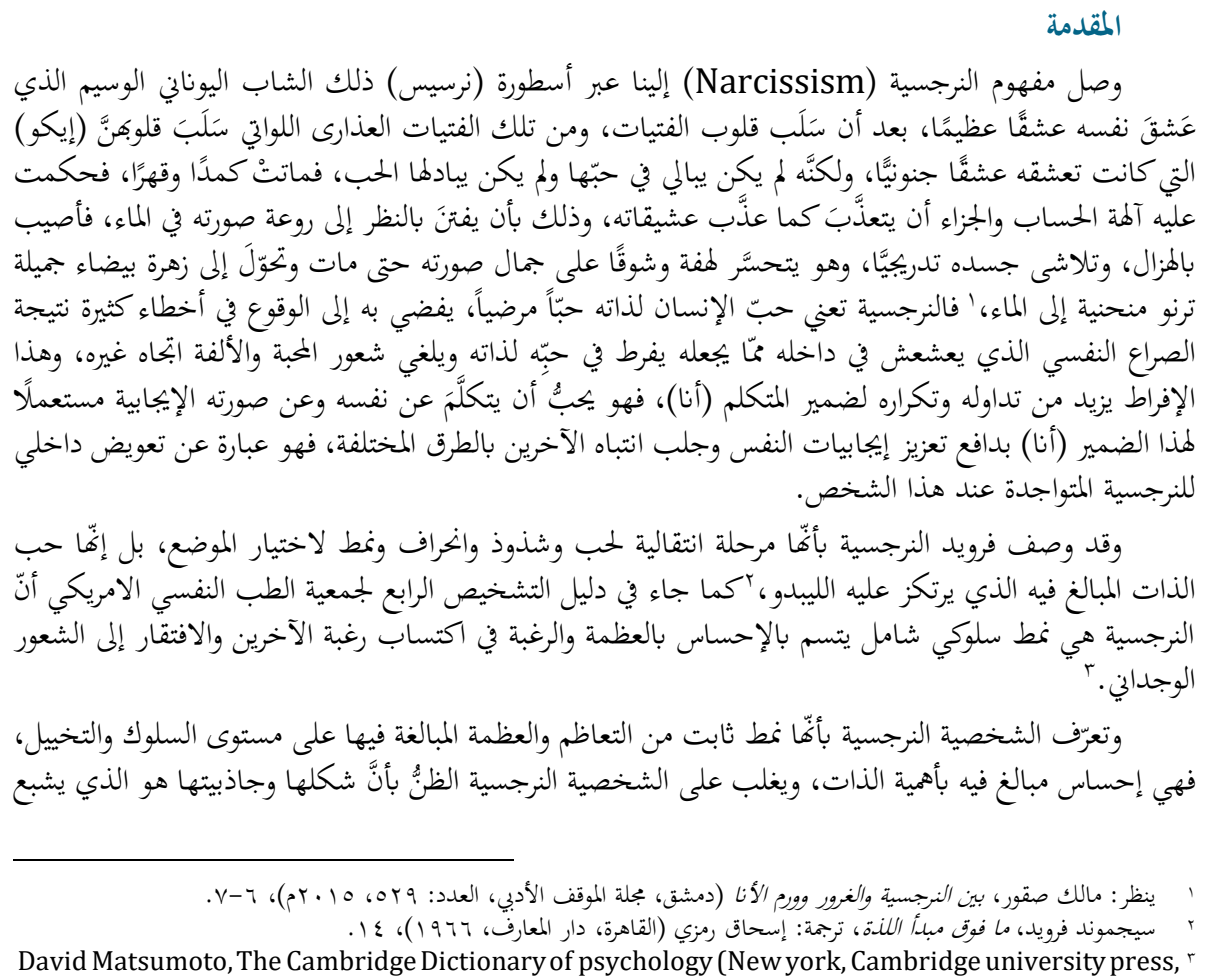
2009), 326. 
رغباتما، فهي تركّز على النقاط التي تظهرها بأجمل صورة وأفضل وجه. ؛ كما جاء في قاموس كمبردج أنَّا ميول الفرد

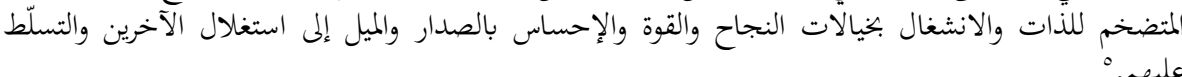

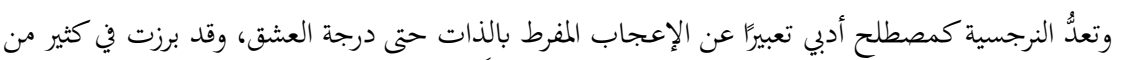

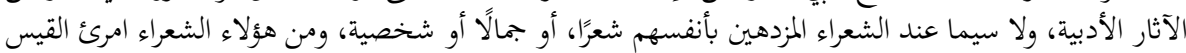

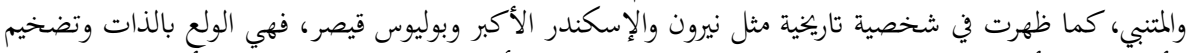

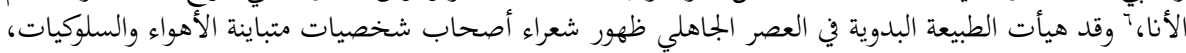

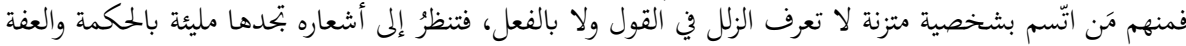

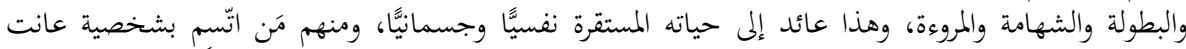

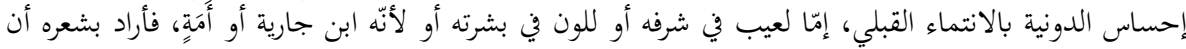

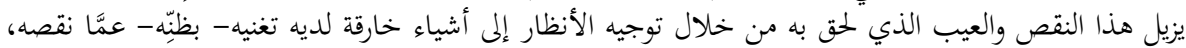

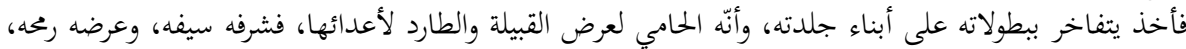

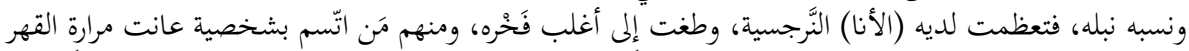

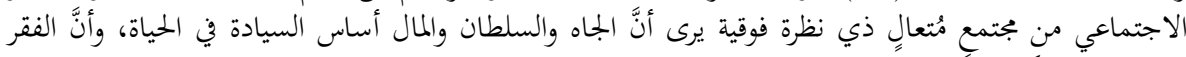

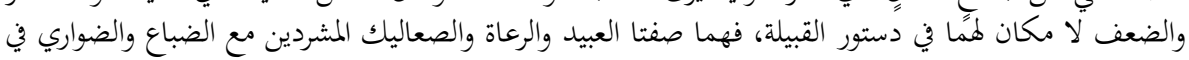

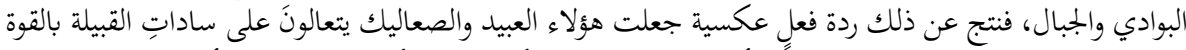

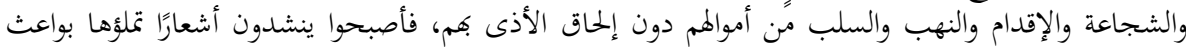

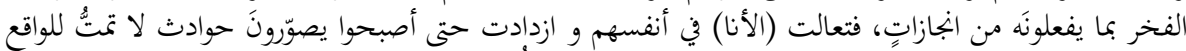

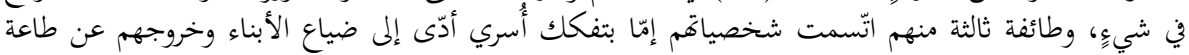

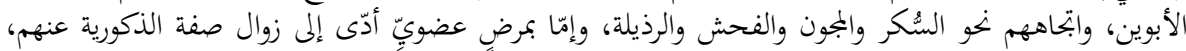

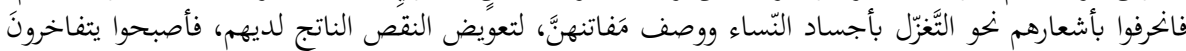

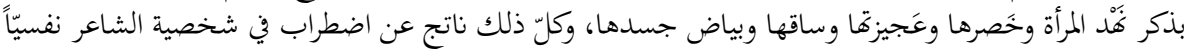

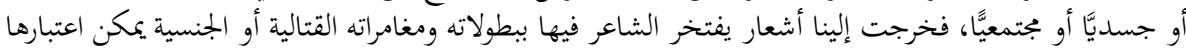
أشعار الفخر النرجسي.

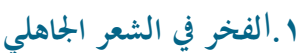

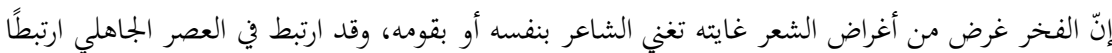

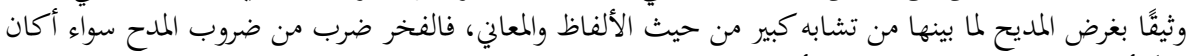

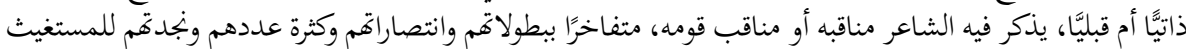

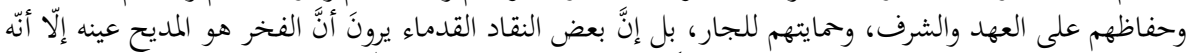

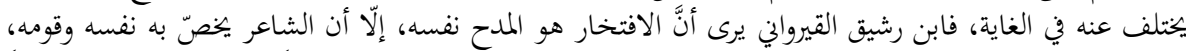

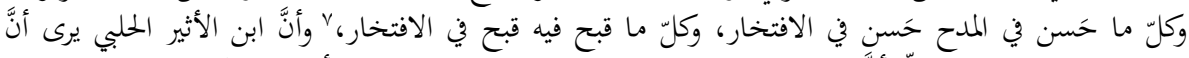

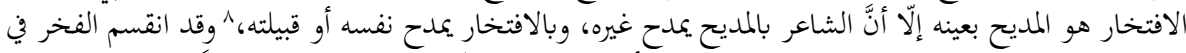

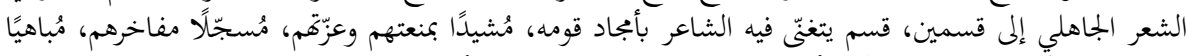

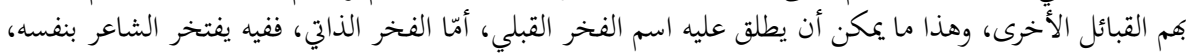

آمال جودة، النرجسية وعلاقتها بالعصبية للدى عينة من طلبة جامعة الأقصى (غزة، مجلة الجامعة الإسـلامية للدراسـات التربوية والنفسية،

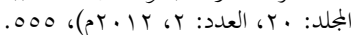

factor model of -Robert Michael Bagby, And others, Dsm-Iv personality disorders and the five personality: Amulti-method examination of domain and facet-level predictions (USA, Eurpean Journal of personality, 19/4, 2005), 156.

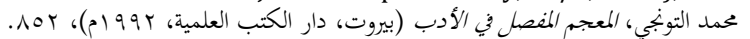

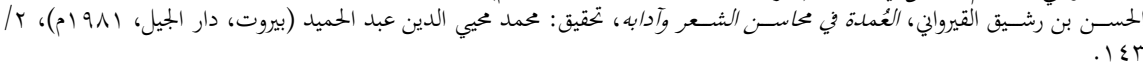

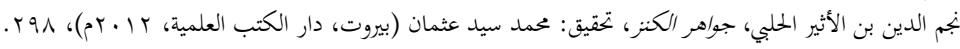




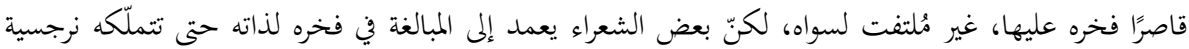

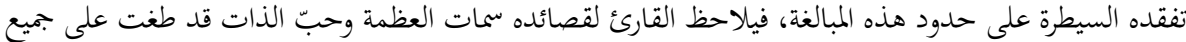
ألفاظه ومعانيه.

$$
\text { | أ. أنشأة الفخر في الشعر الجاهلي }
$$

بدأت نشأة الفخر في العصر الجاهلي نشأة عفويَّة، انطلاقًا من غلبة النزعة القبلية على هذا الغرض الشعريّ، وقد غذّى هذه النشأة عدّة عوامل، أهمّها:

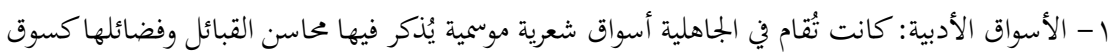

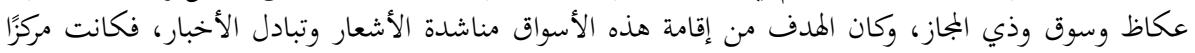

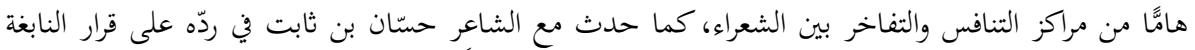

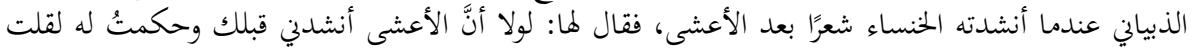

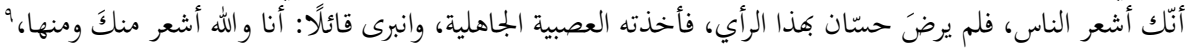

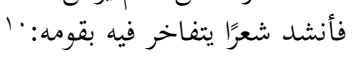

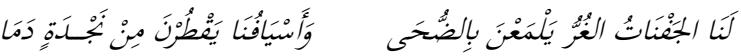

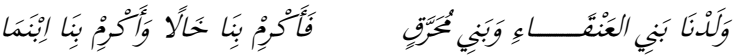

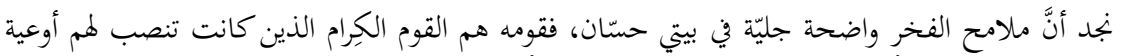

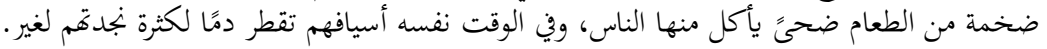

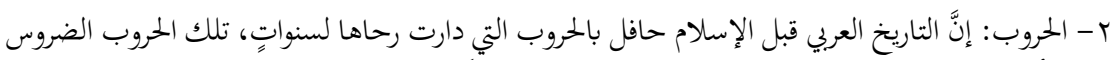

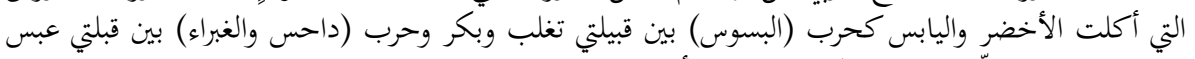

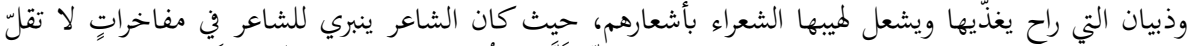

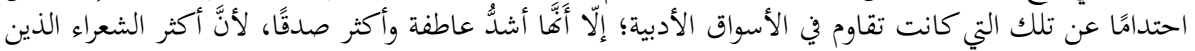

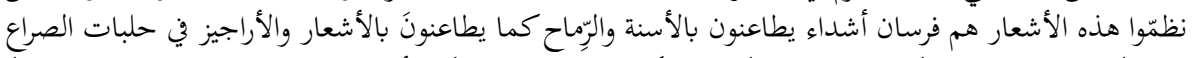

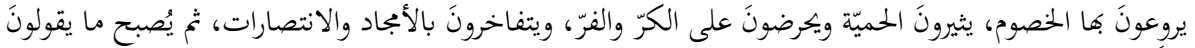

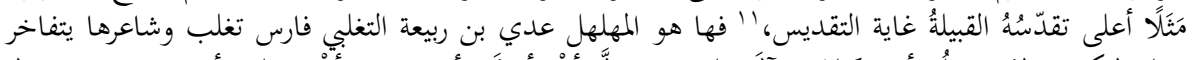

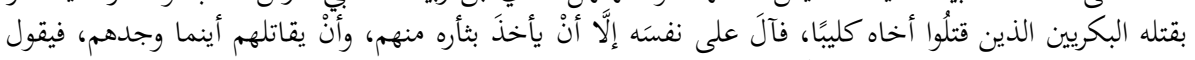

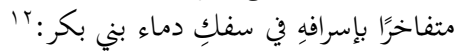

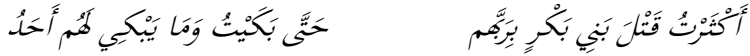

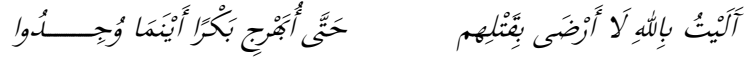

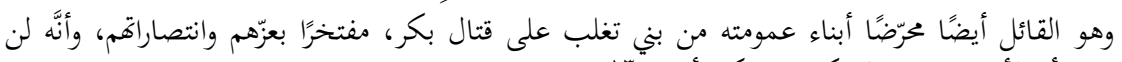

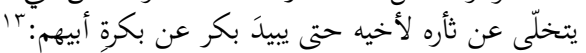

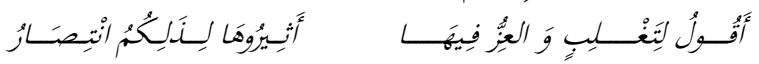

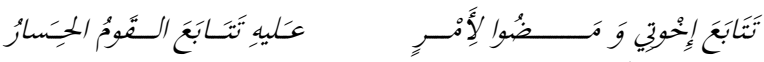

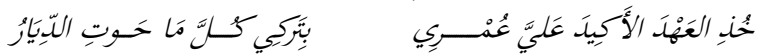

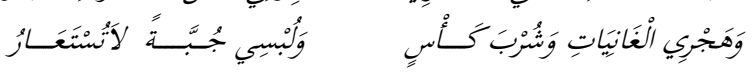

" ينظر : عبد القادر بن عمر البغدادي، خزانة الأدب ولب لباب لسان العرب، ت: عبد السلام هارون (القاهرة، مكتبة الخانجي، لو9 ام)، $.111-11 \cdot / 1$

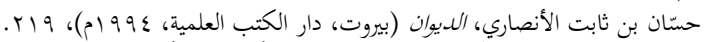

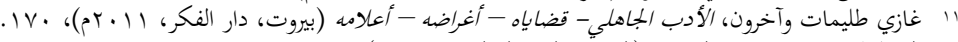

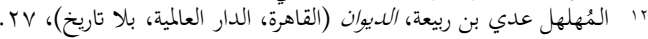

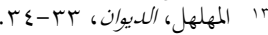




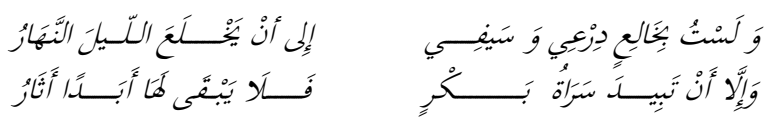

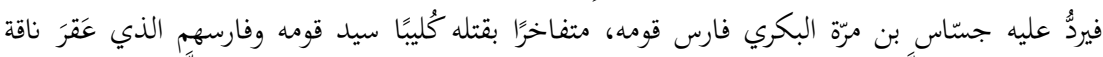

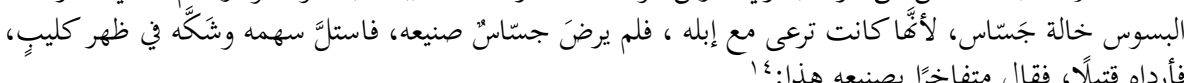

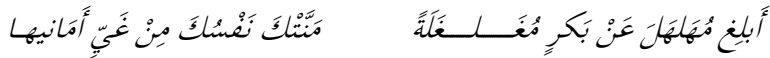

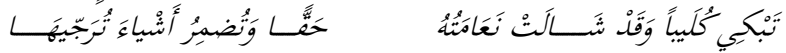

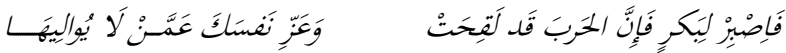

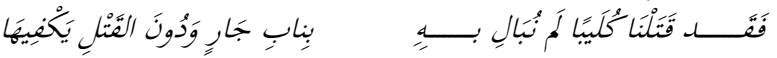

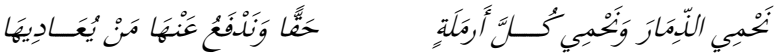

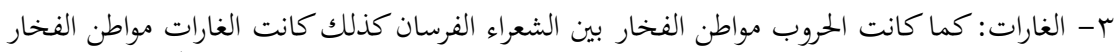

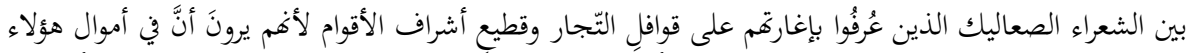

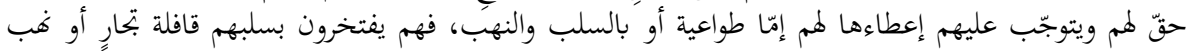

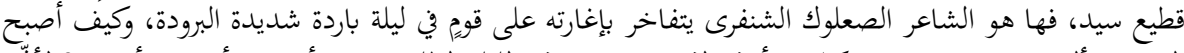

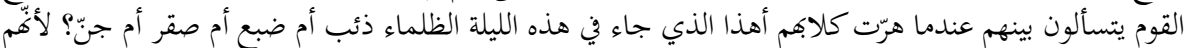

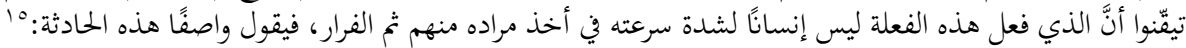

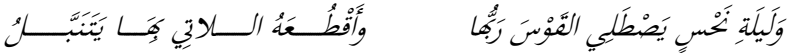

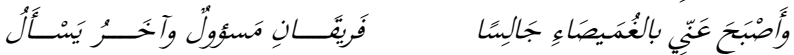

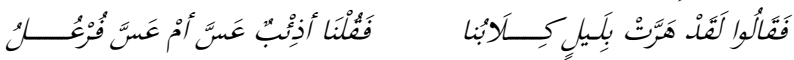

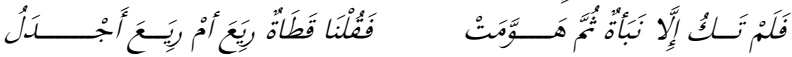

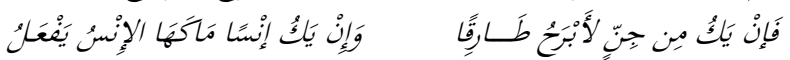

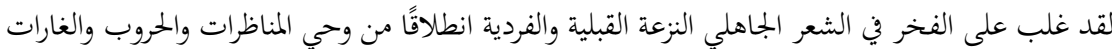

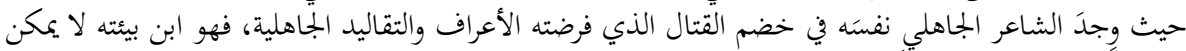

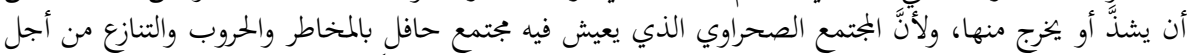

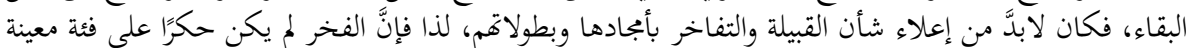

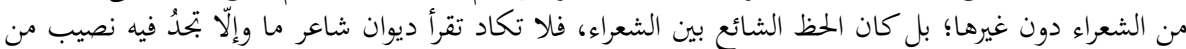

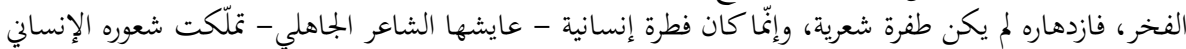

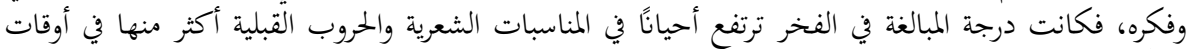

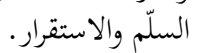

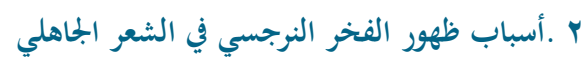

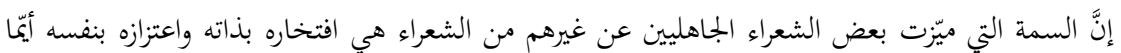

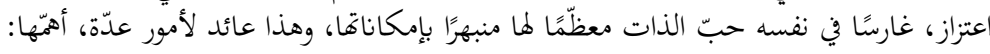

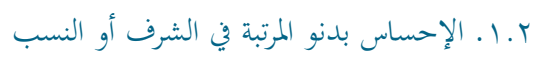

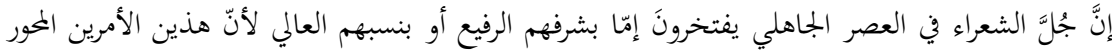

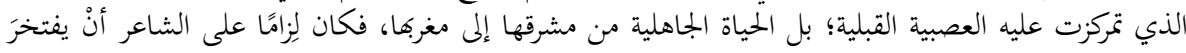




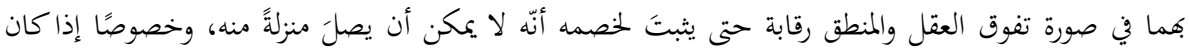

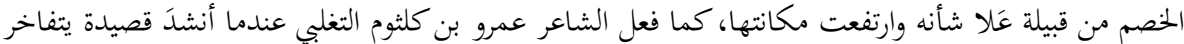

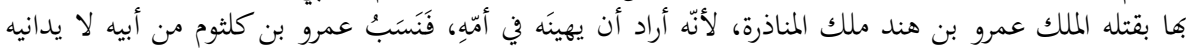

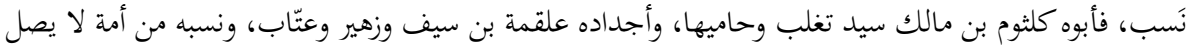

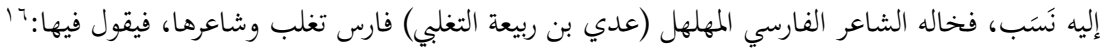

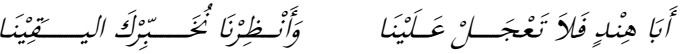

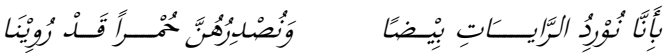

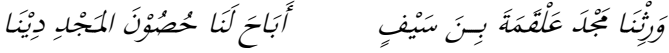

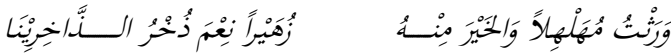

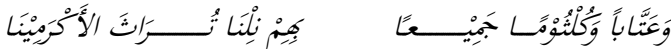

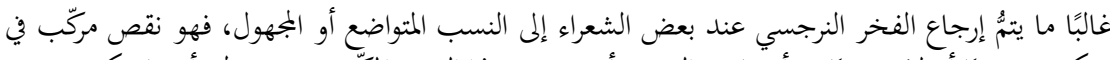

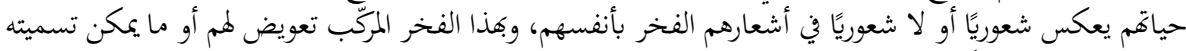

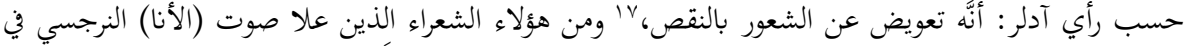

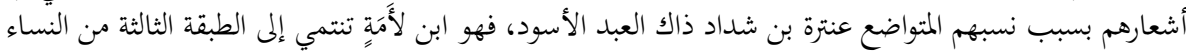

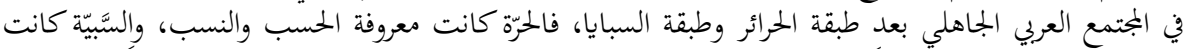

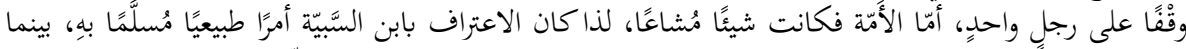

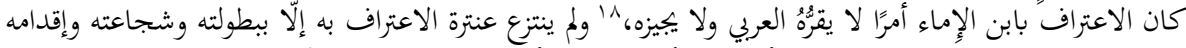

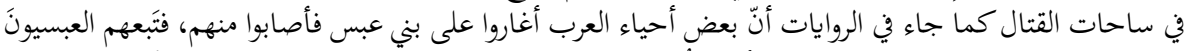

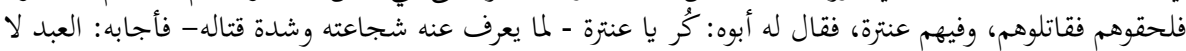

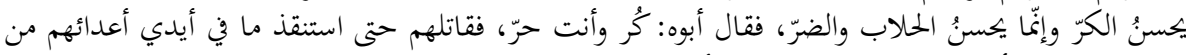

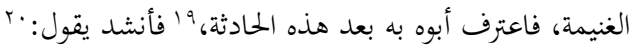

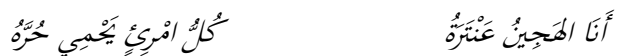

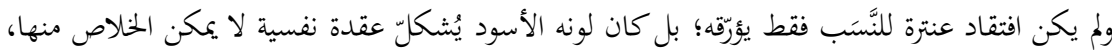

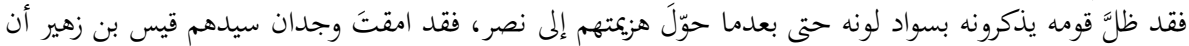

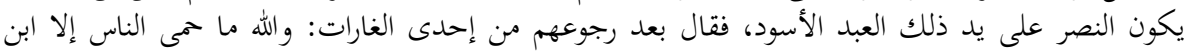

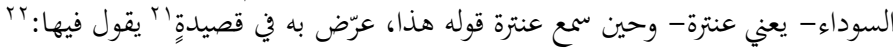

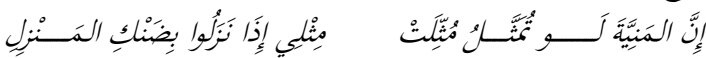

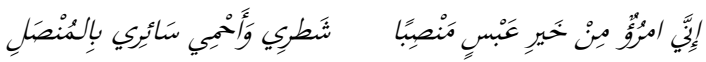

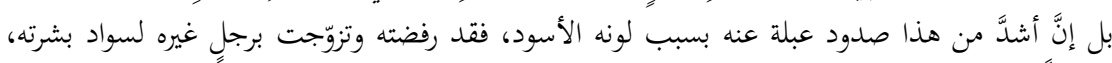
فيخاطبها قائلاً: بr

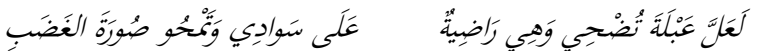

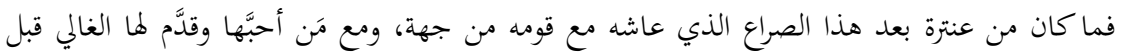

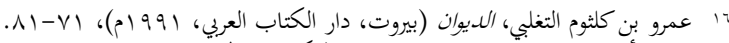

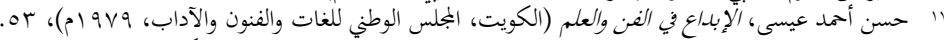

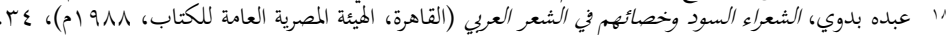

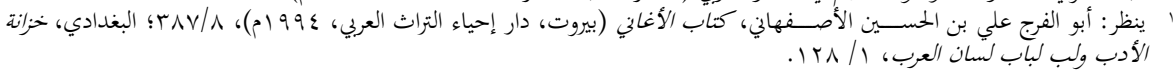

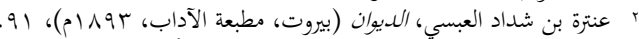

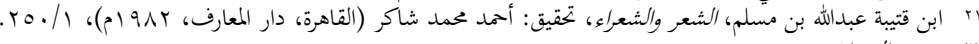

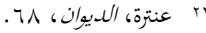

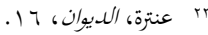



ونسبه كما يقول: ترضى به على سواد لونه إلّا أن يتعالى على قومه مفتخرًا بشجاعته وبطولته وسيفه ورمحه، فهؤلاء شرفه

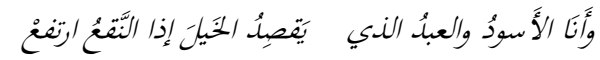

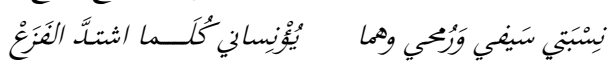

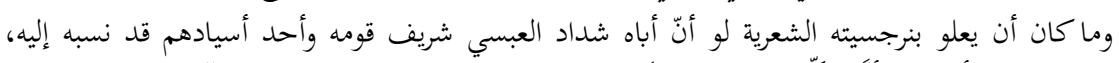

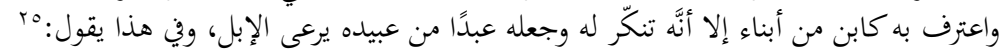

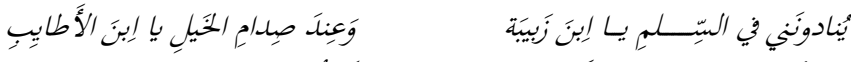

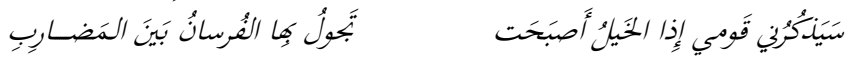

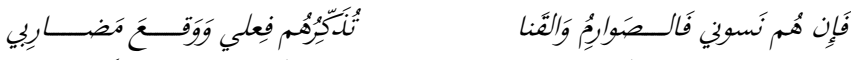

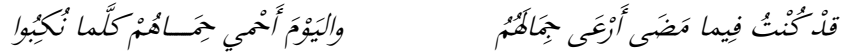

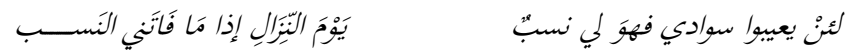

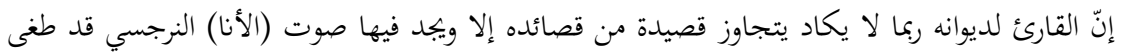

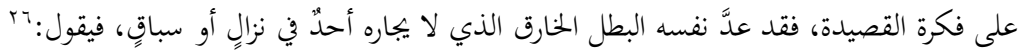

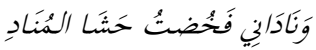

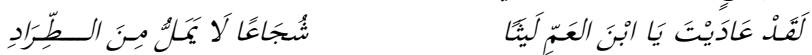

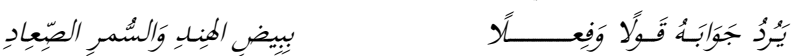

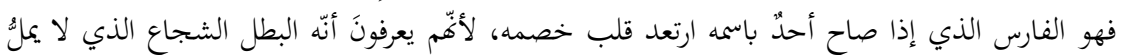

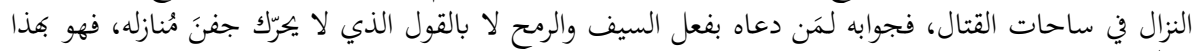

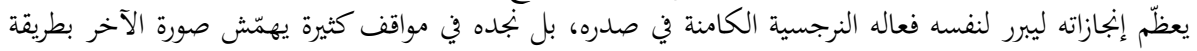

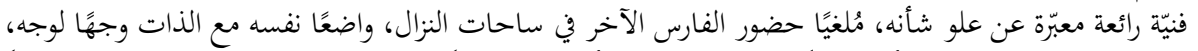

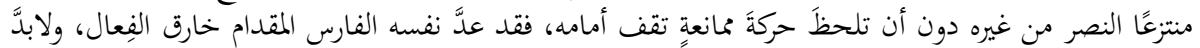

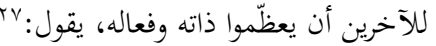

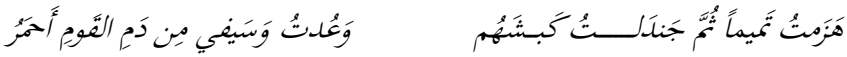

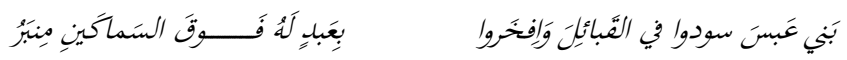

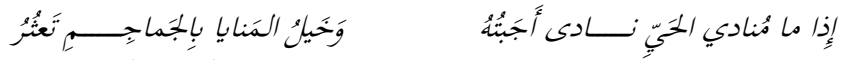

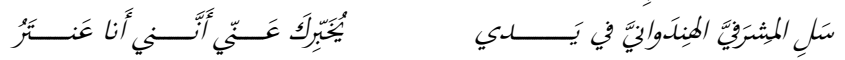

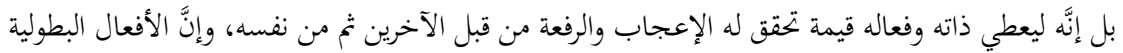

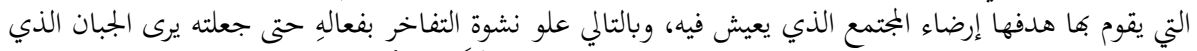

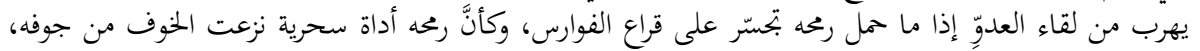

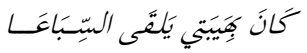

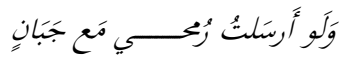

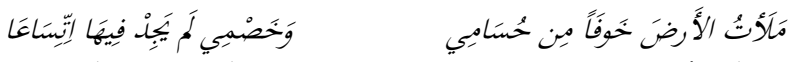

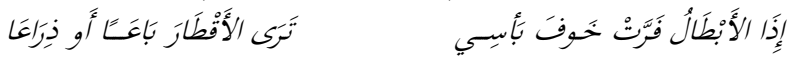




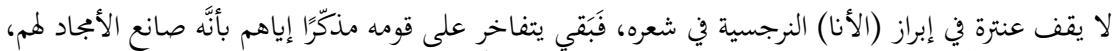

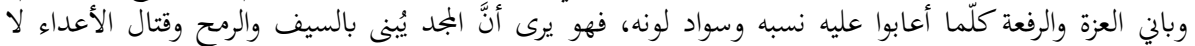

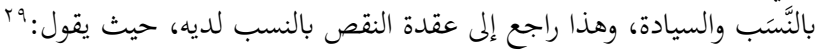

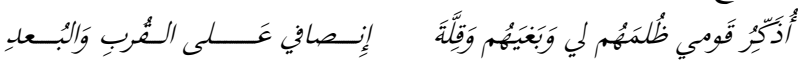

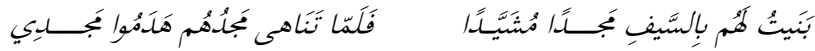

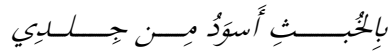

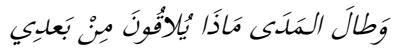

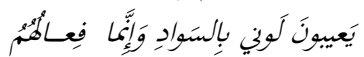

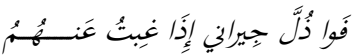

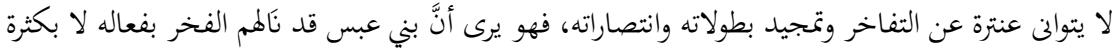

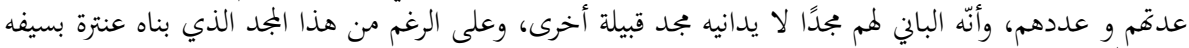

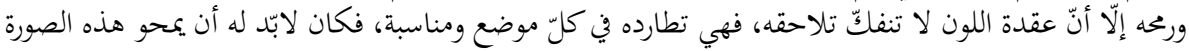

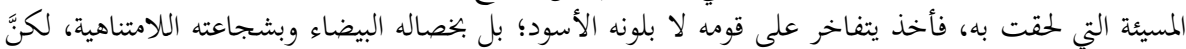

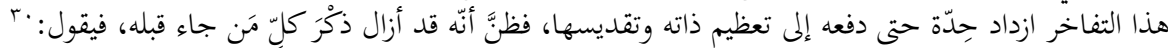

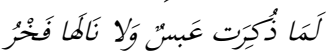

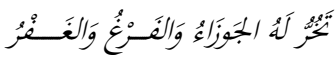

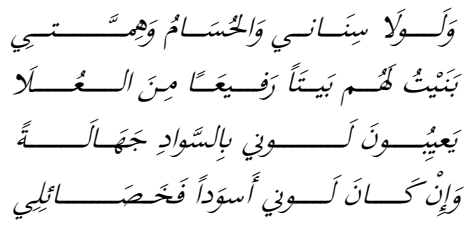

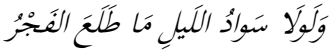

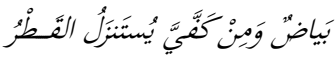

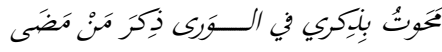

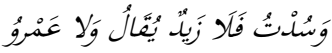

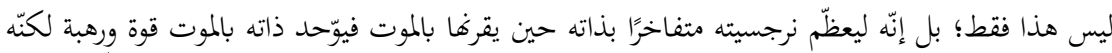

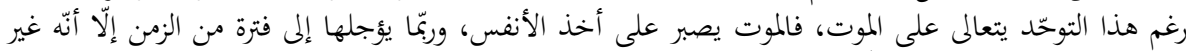

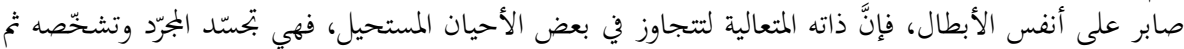

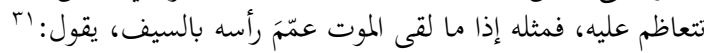

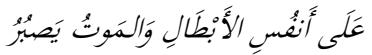

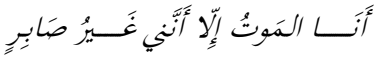

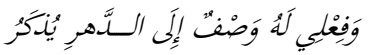

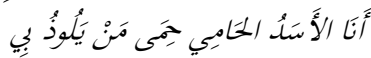

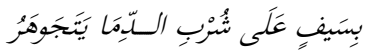

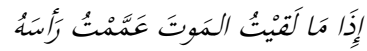

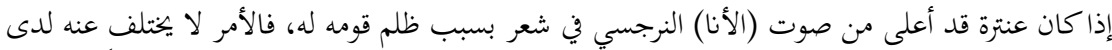

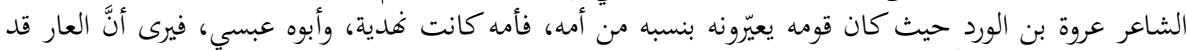

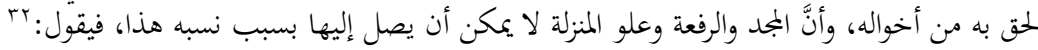

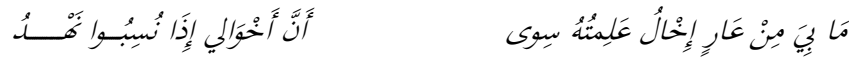

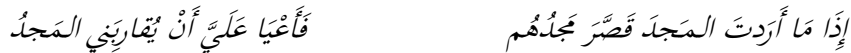

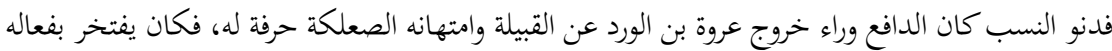

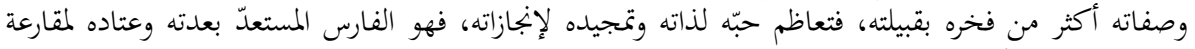

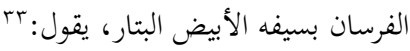

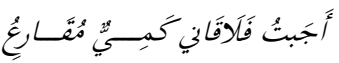

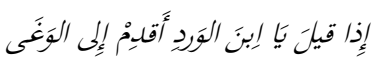




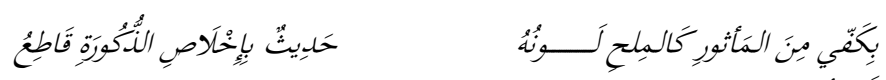

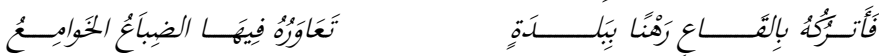

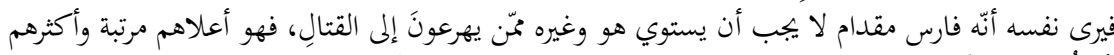

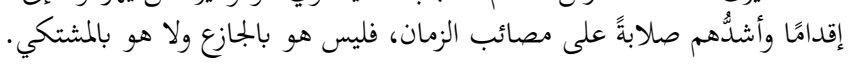

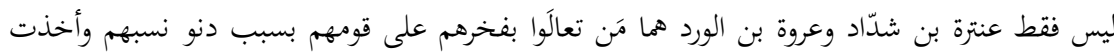

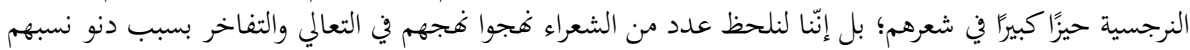

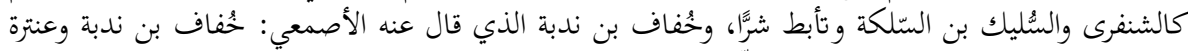

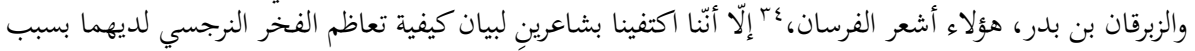

$$
\text { دنو نسبهما. }
$$

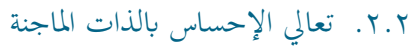

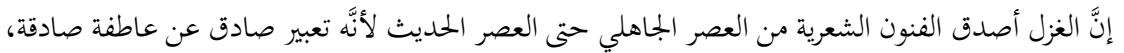

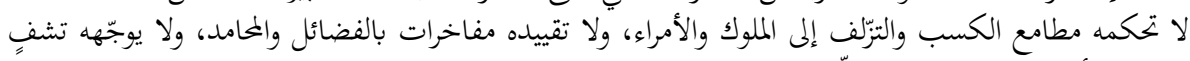

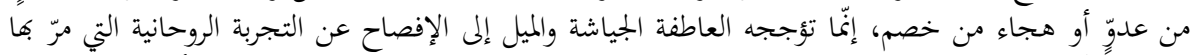

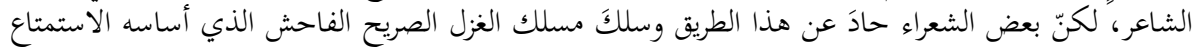

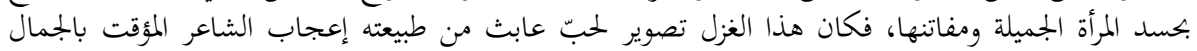

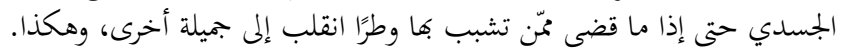

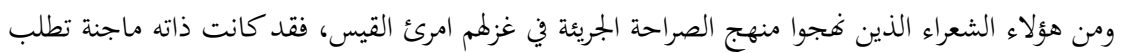

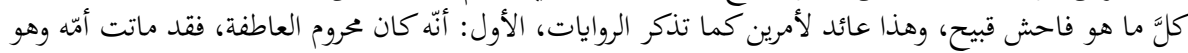

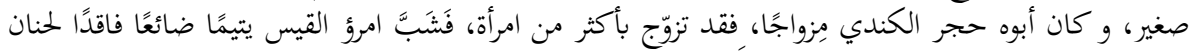

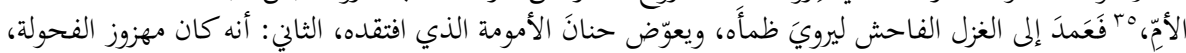

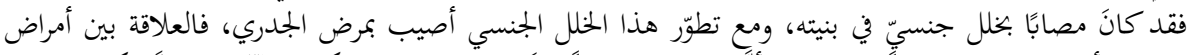

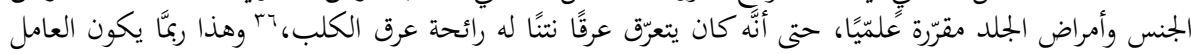

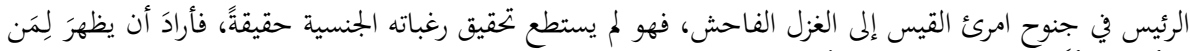

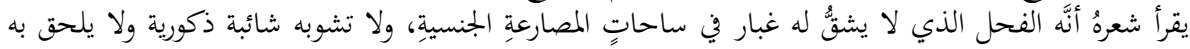

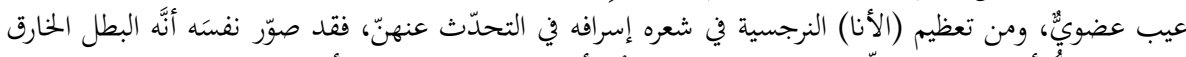

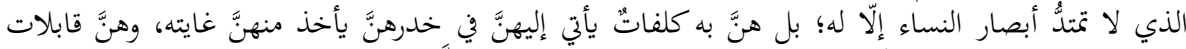

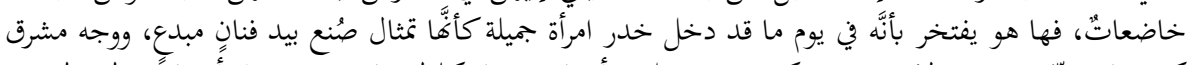

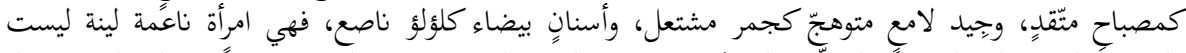

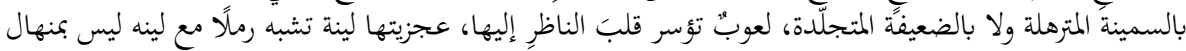

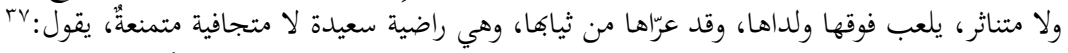

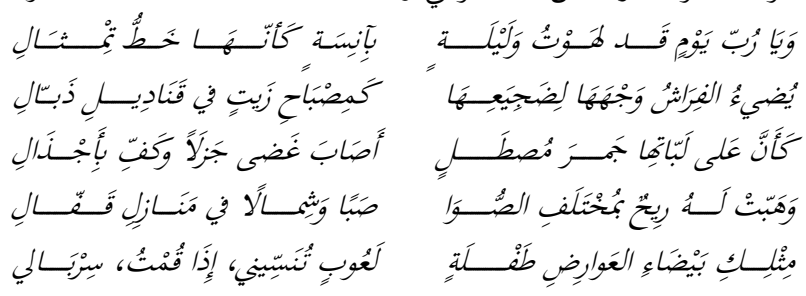

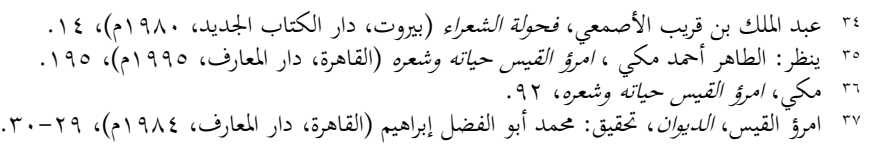




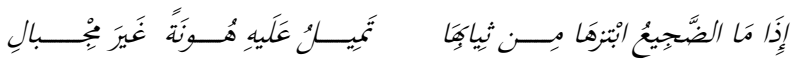

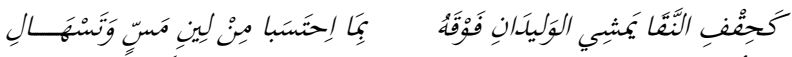

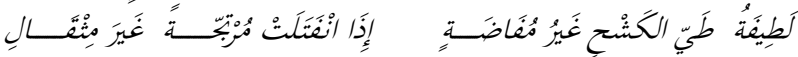

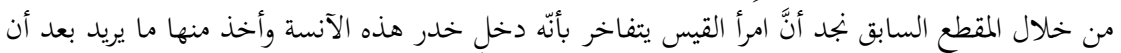

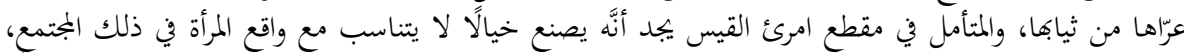

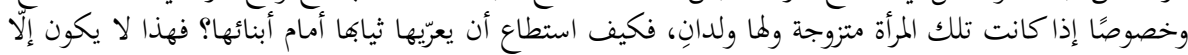

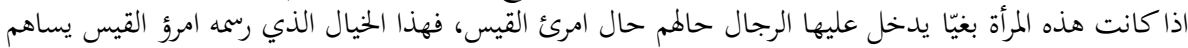

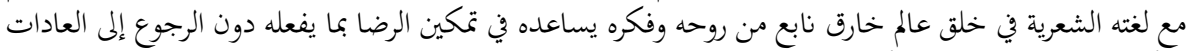

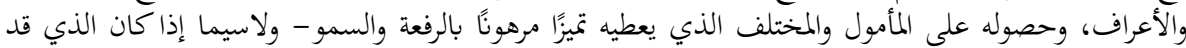

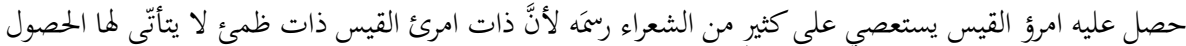

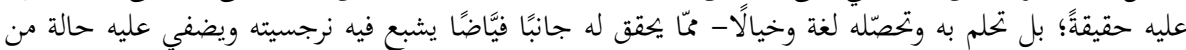

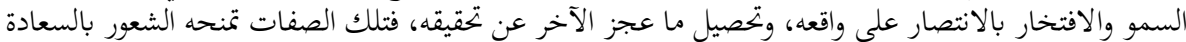

$$
\text { والنشوة، وتشهد على تمييزه. }
$$

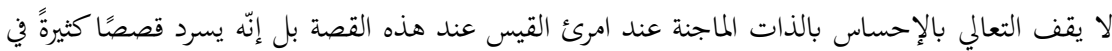

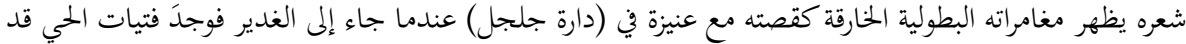

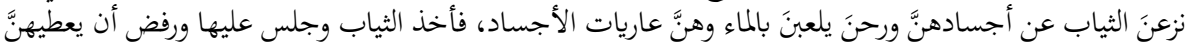

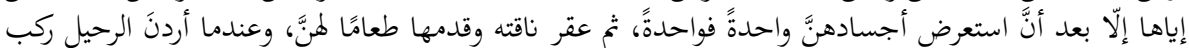

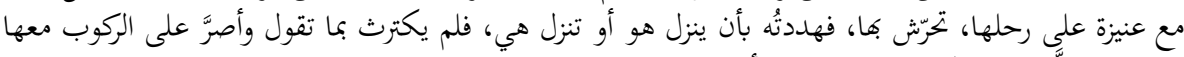

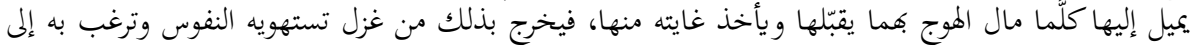

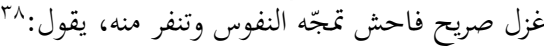

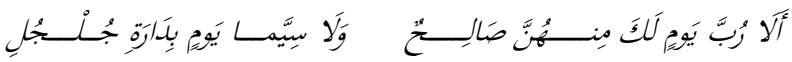

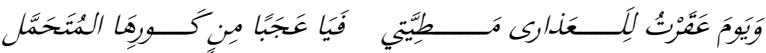

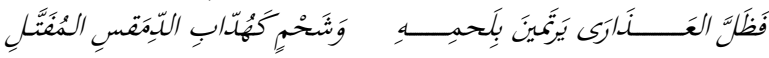

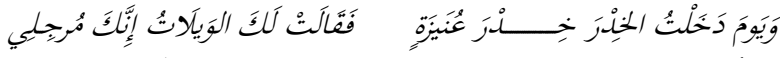

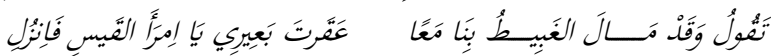

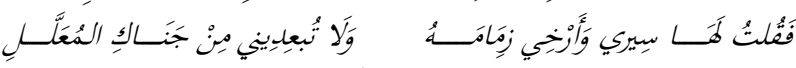

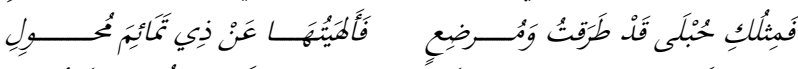

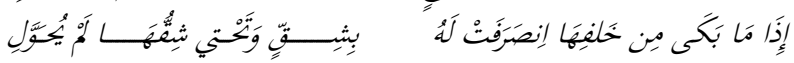

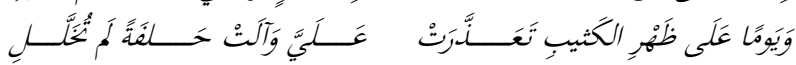

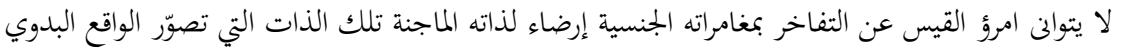

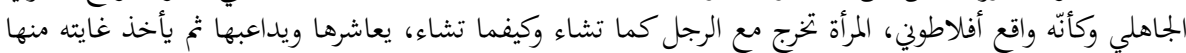

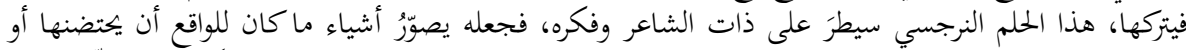

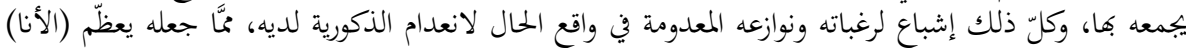

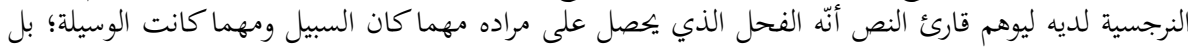

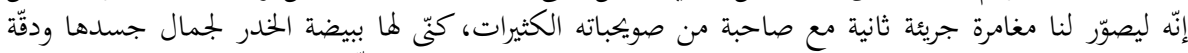

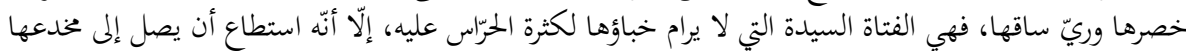

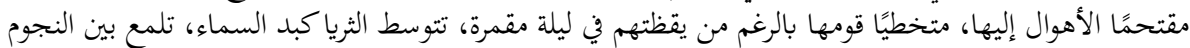

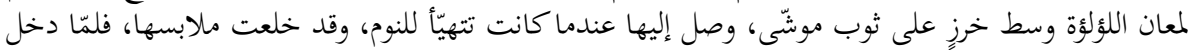




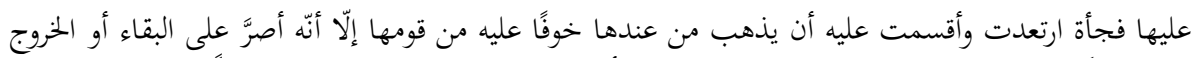

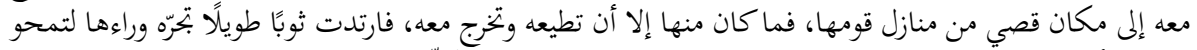

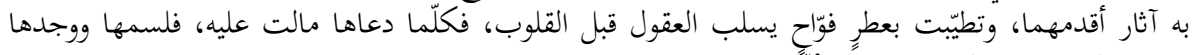

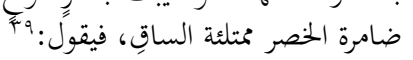

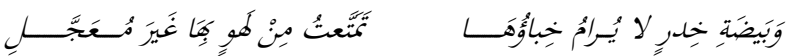

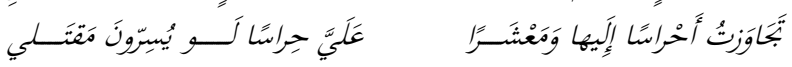

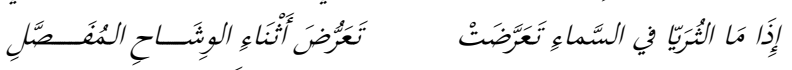

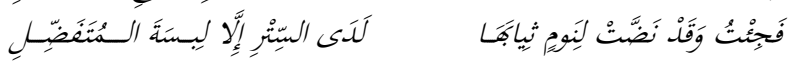

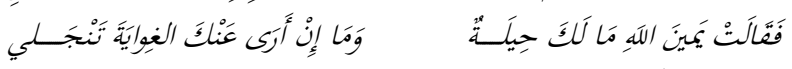

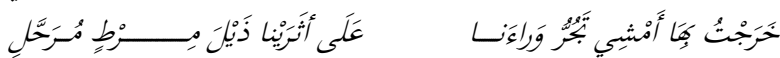

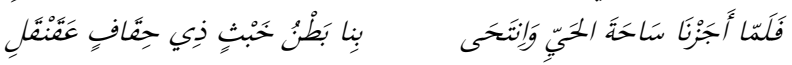

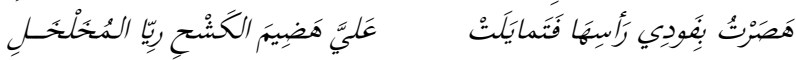

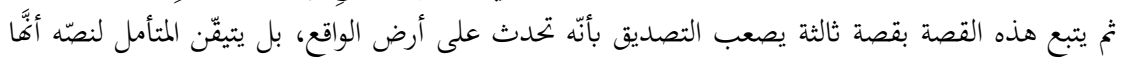

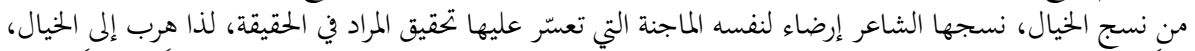

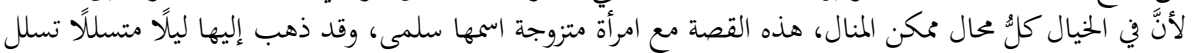

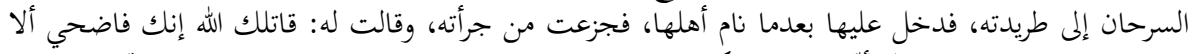

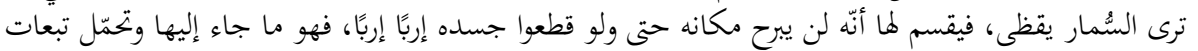

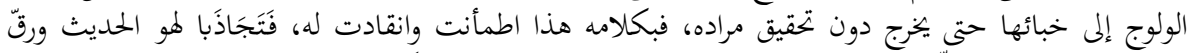

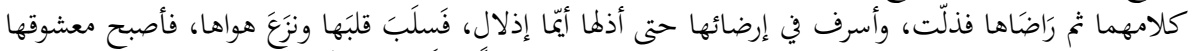

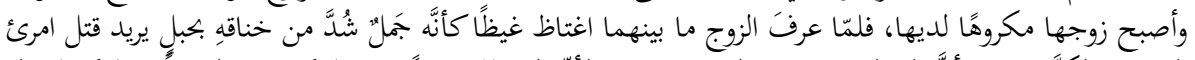

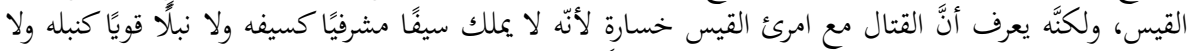

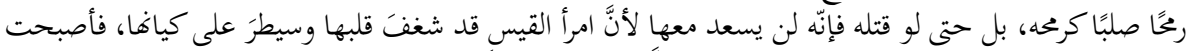

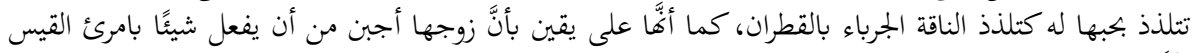

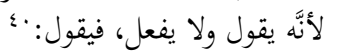

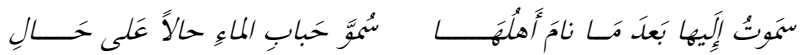

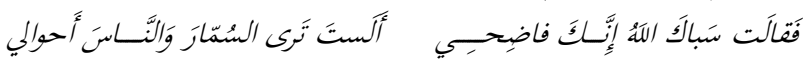

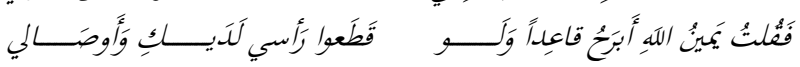

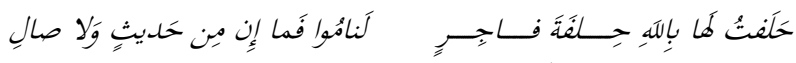

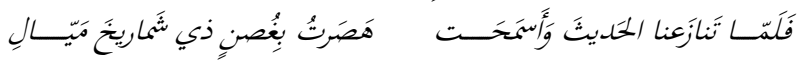

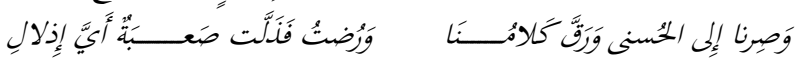

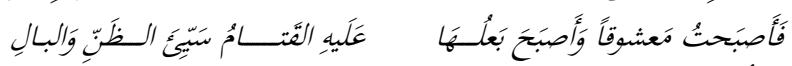

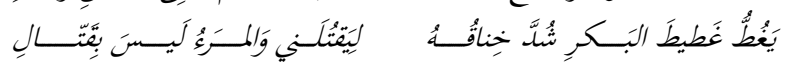

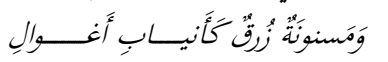

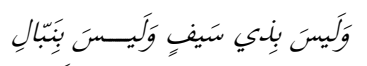

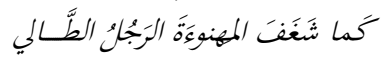

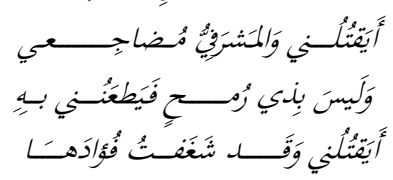




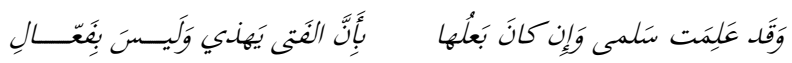

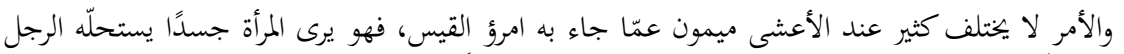

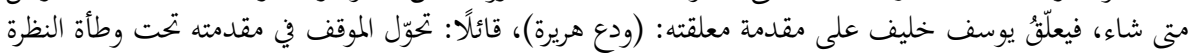

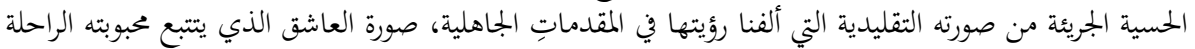

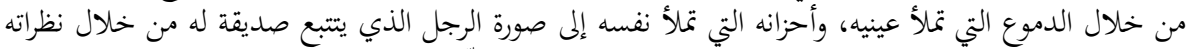

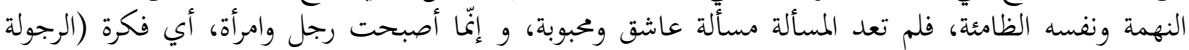

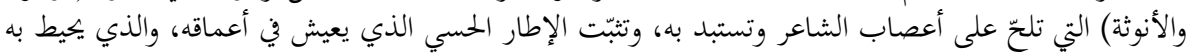

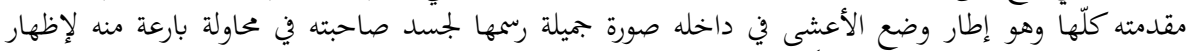

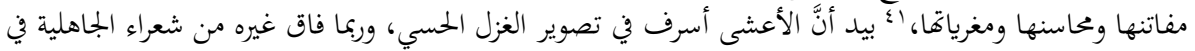

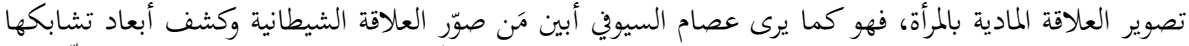

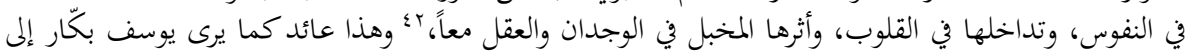

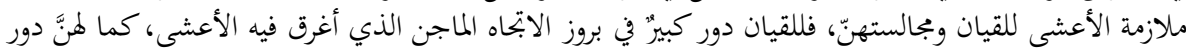

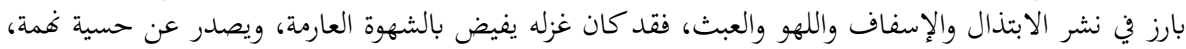

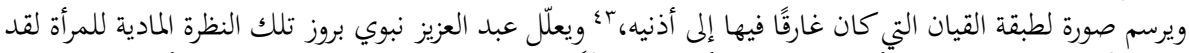

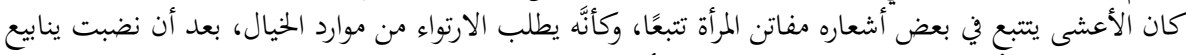

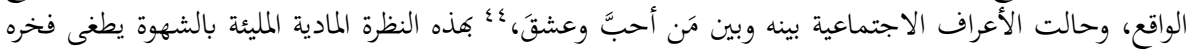

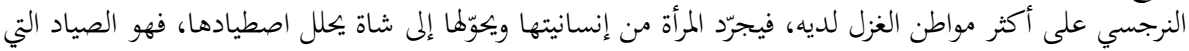

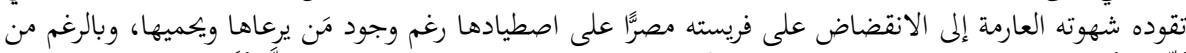

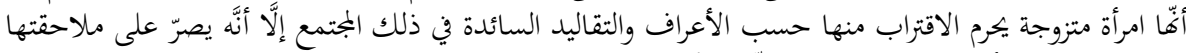

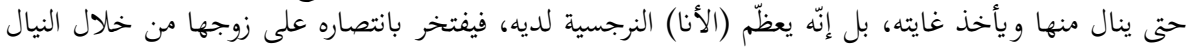

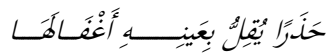

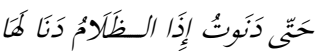

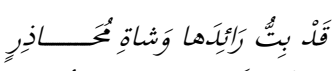

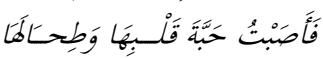

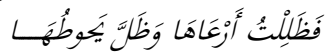

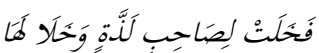

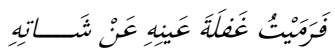

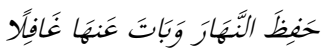

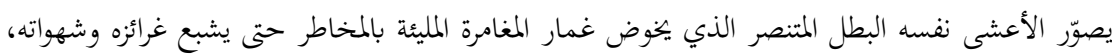

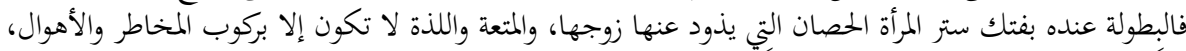

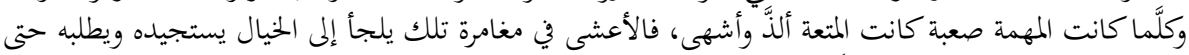

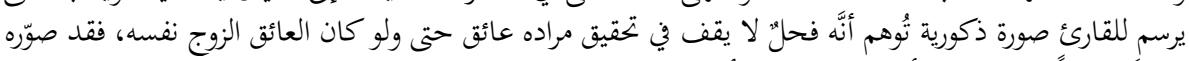

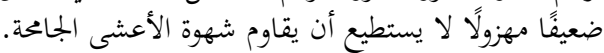

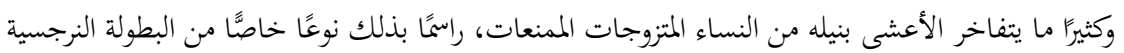

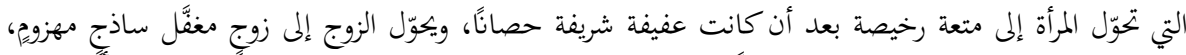

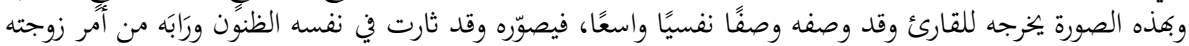

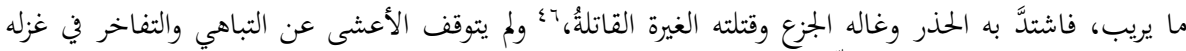

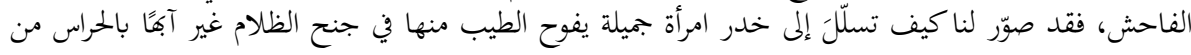

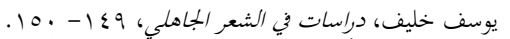

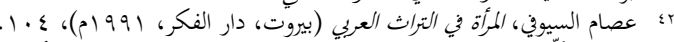

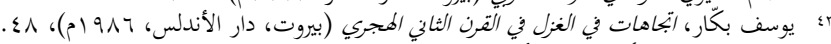

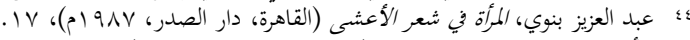

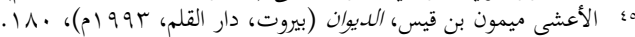

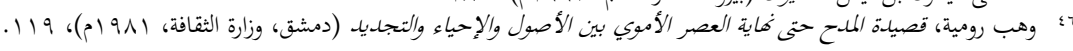




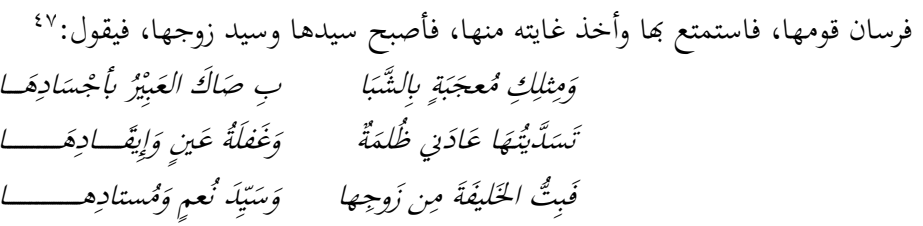

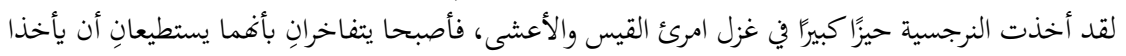

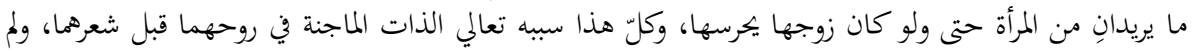

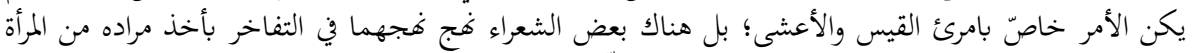

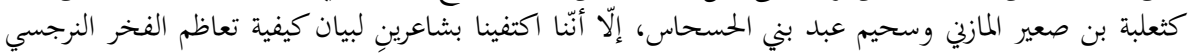
لديهما بسبب تعالي الذات الماجنة.

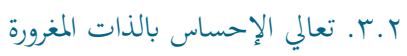

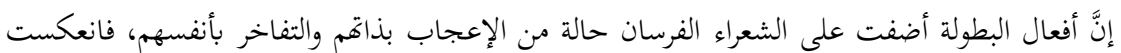

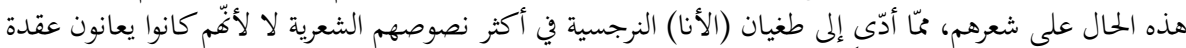

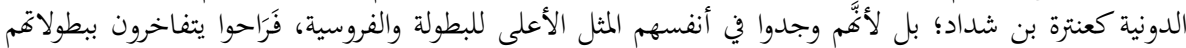

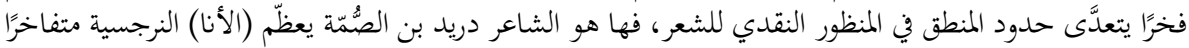

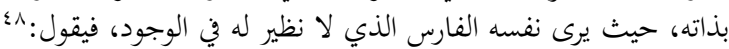

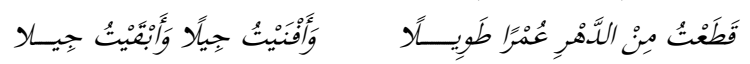

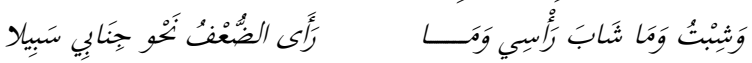

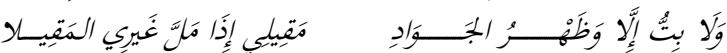

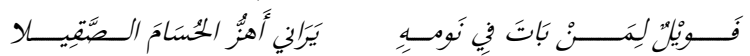

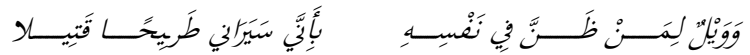

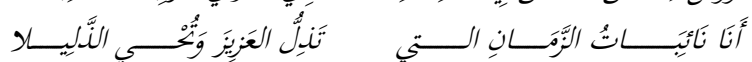

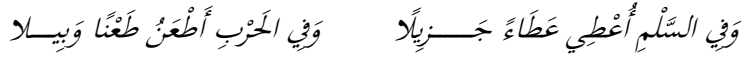

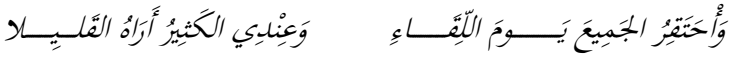

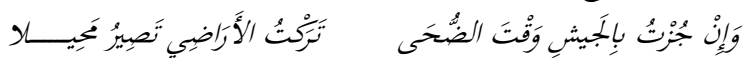

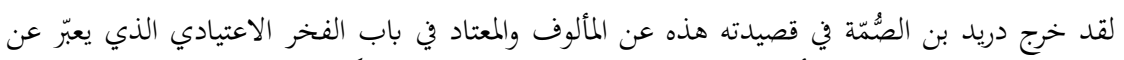

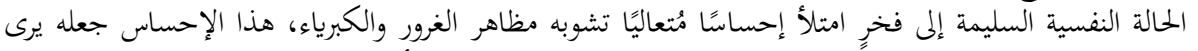

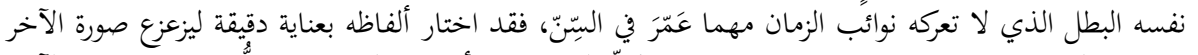

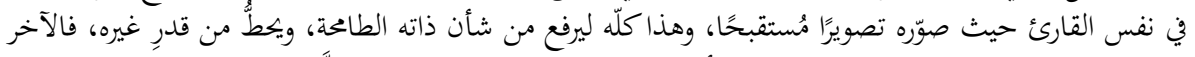

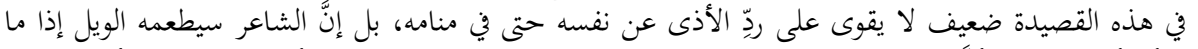

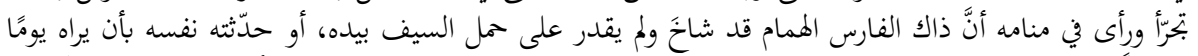

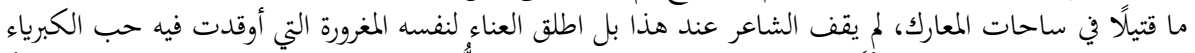

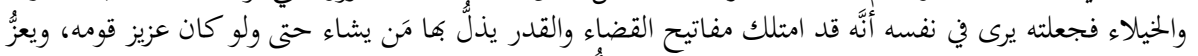

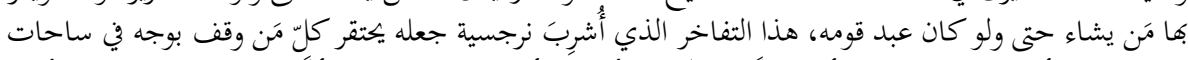

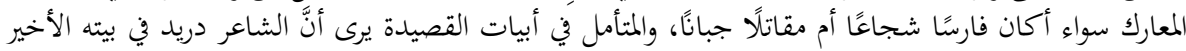

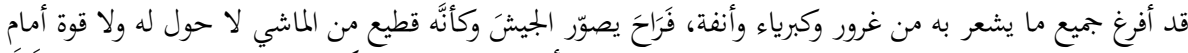

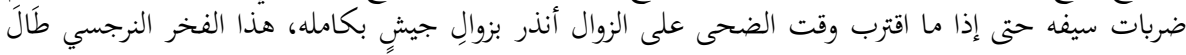




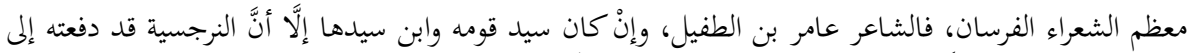

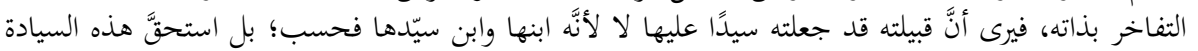

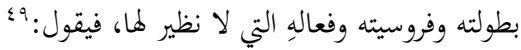

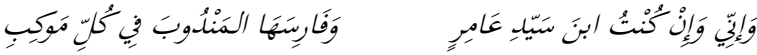

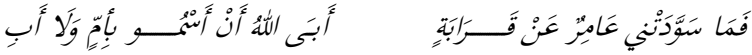

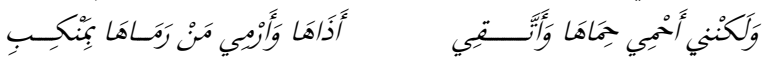

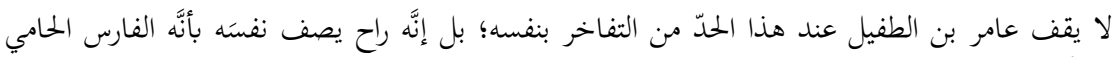

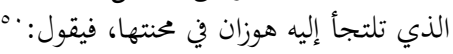

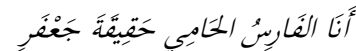

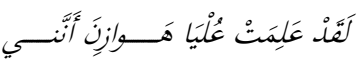

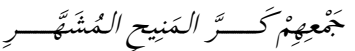

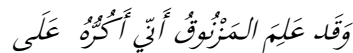

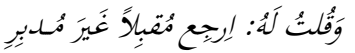

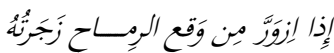

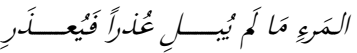

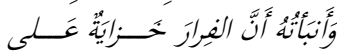

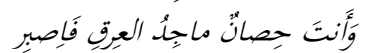

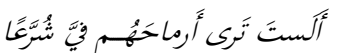

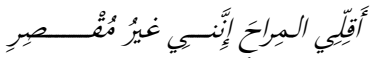

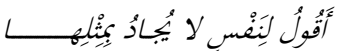

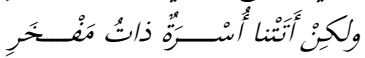

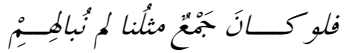

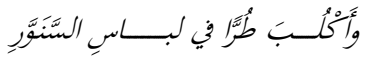

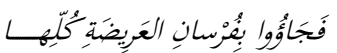

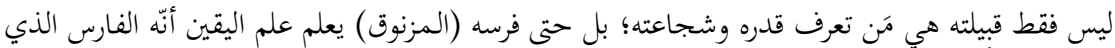

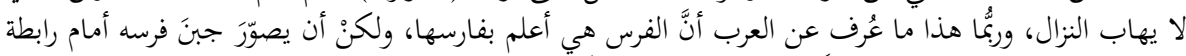

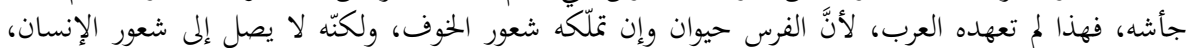

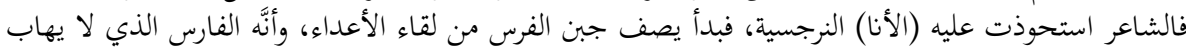

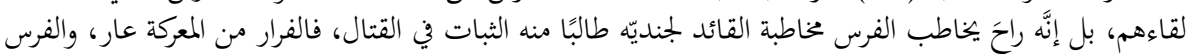

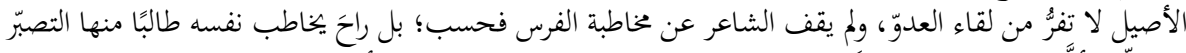

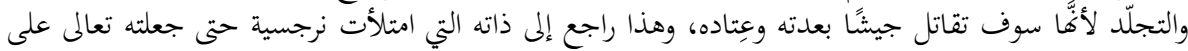

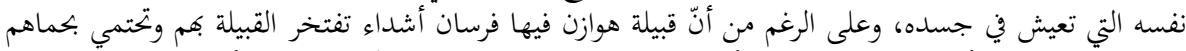

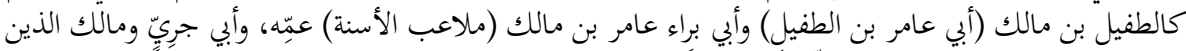

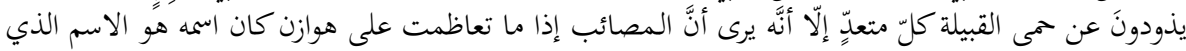

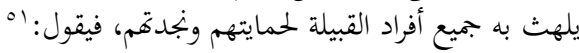

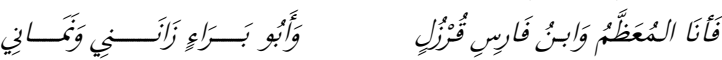

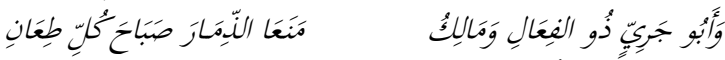

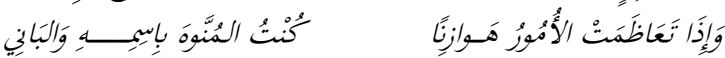

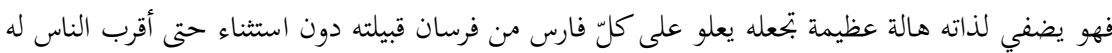

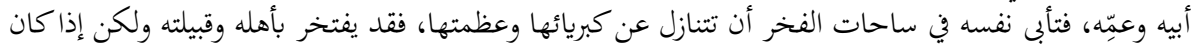

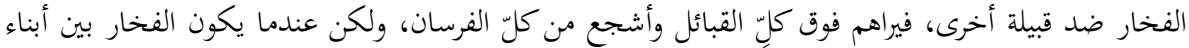

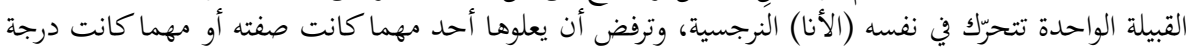




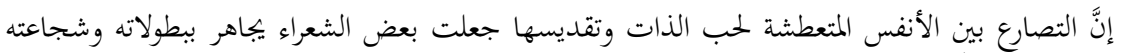

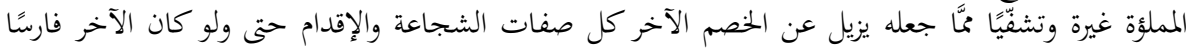

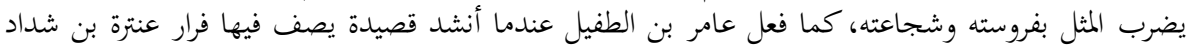

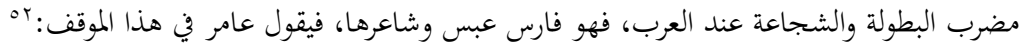

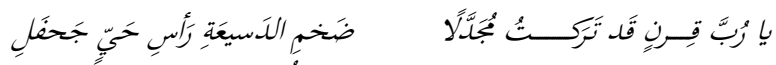

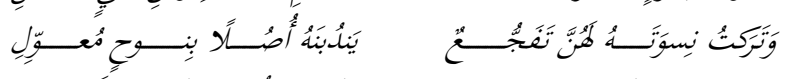

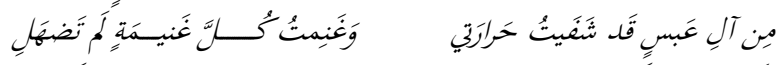

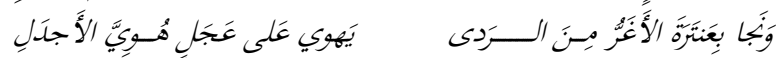

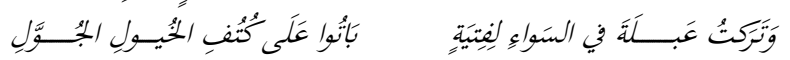

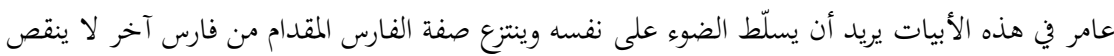

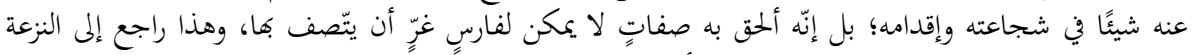

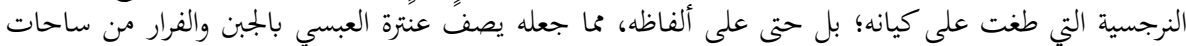

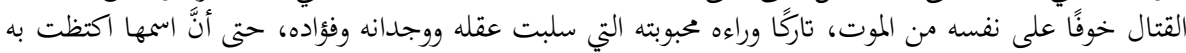

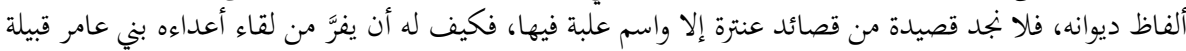

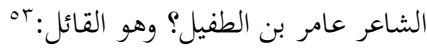

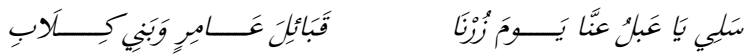

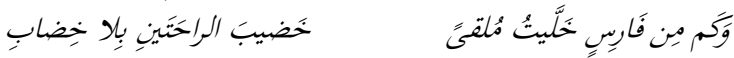

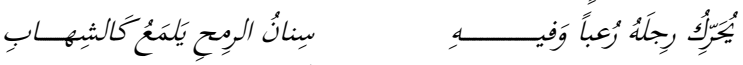

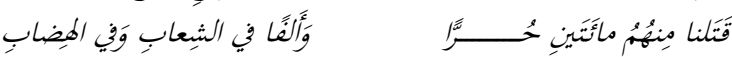

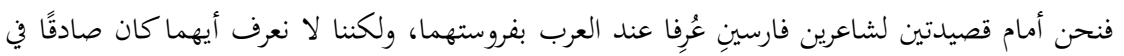

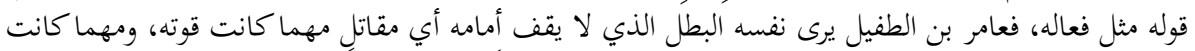

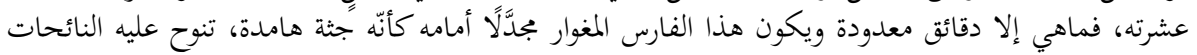

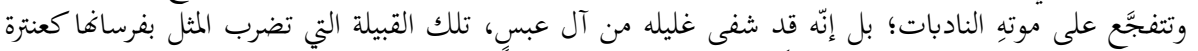

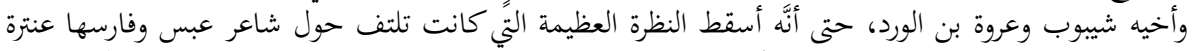

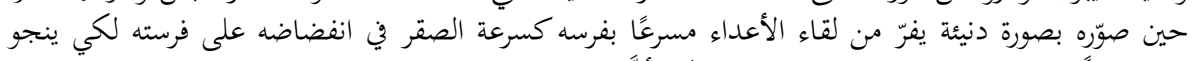

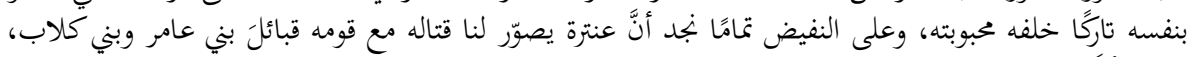

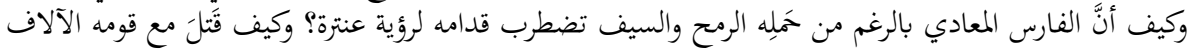

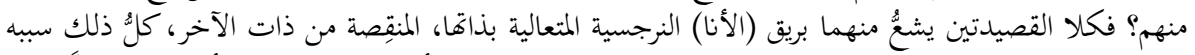

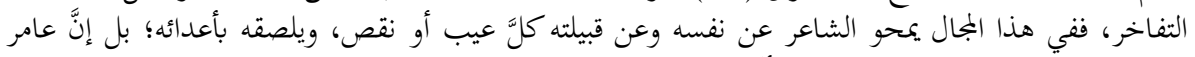

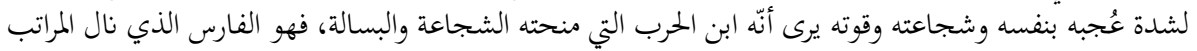

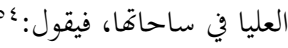

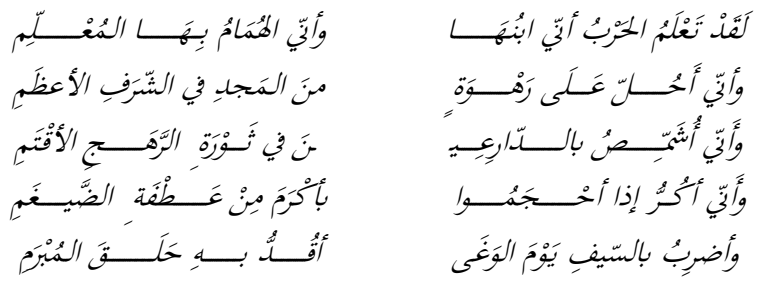

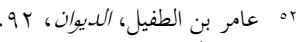

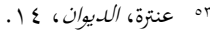

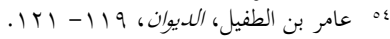




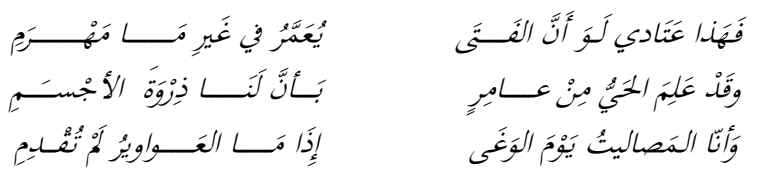

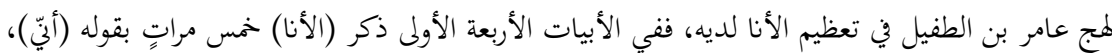

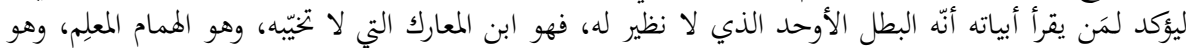

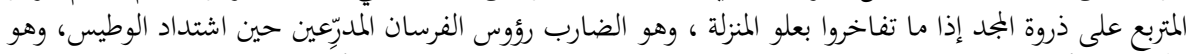

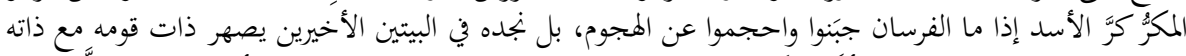

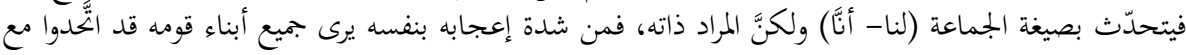

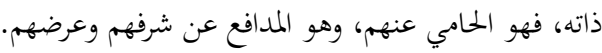

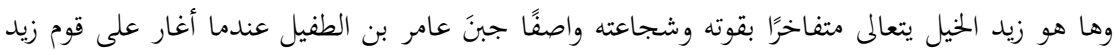

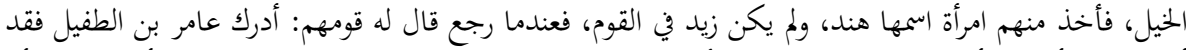

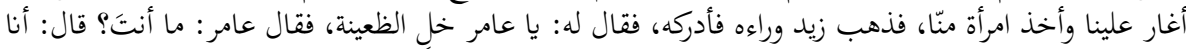

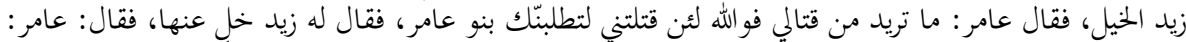

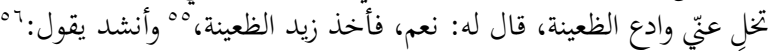

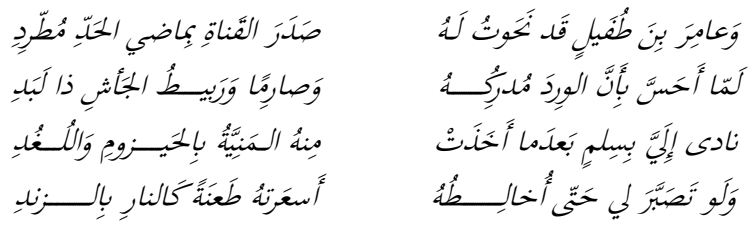

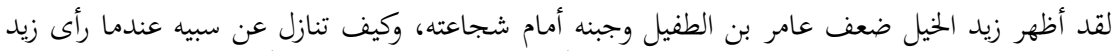

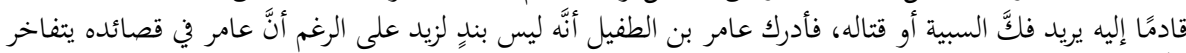

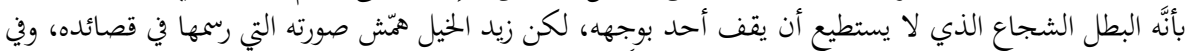

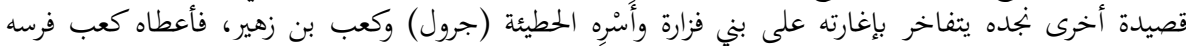

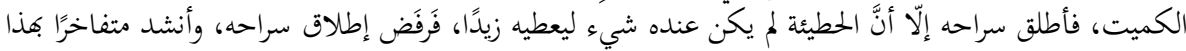

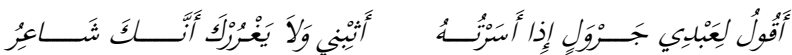

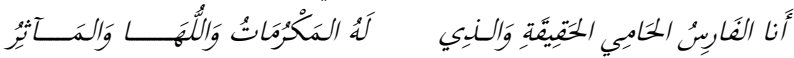

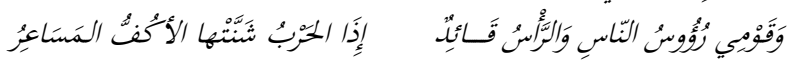

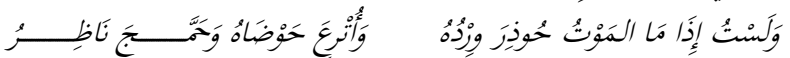

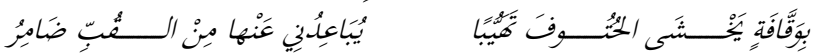

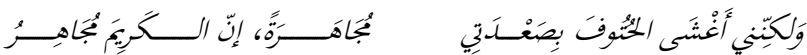

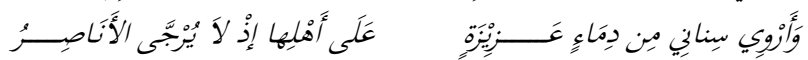

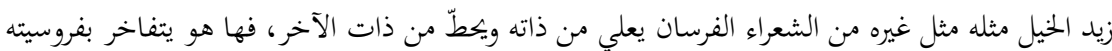

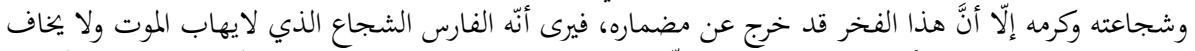

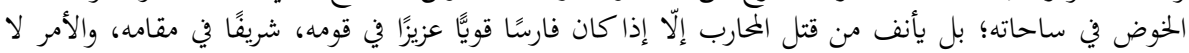

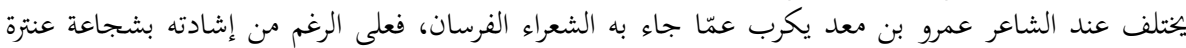

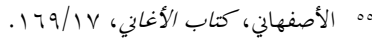

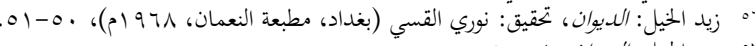


العبسي وعامر بن الطفيل والسُّلك بن السلكة، وعتبة بن الحارث، فهم فرسان العرب المشهورون، إلّاّ أنَّ (الأنا)

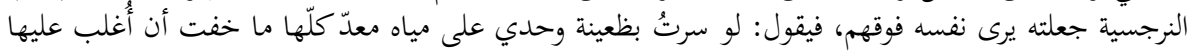

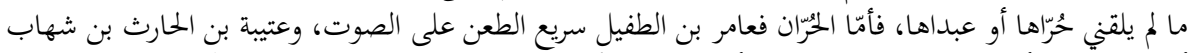

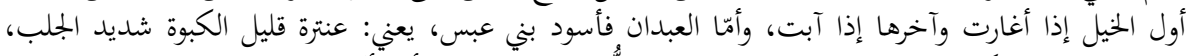

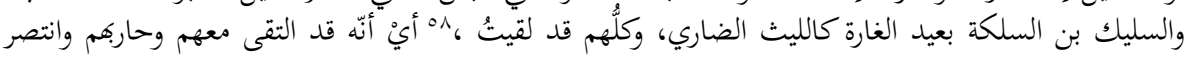

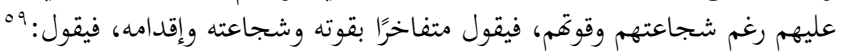

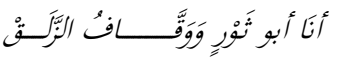

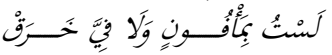

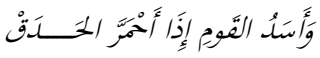

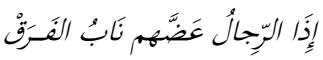

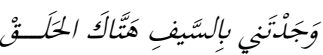

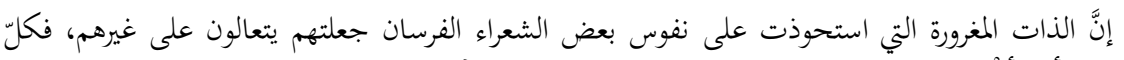

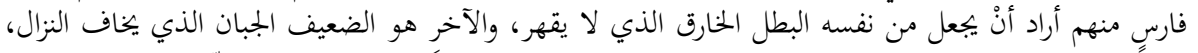

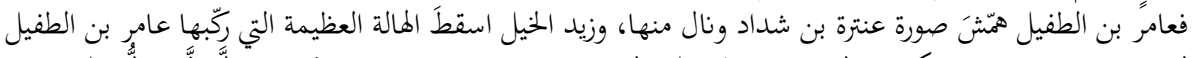

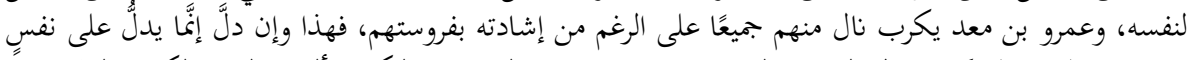

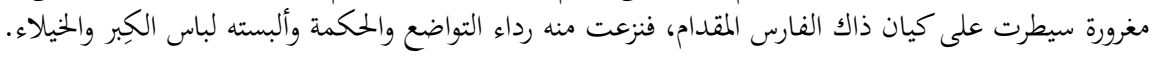

الخاتمة

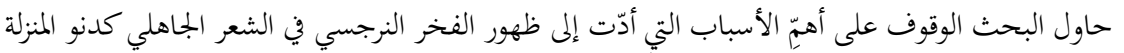

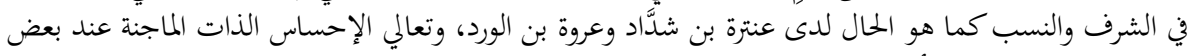

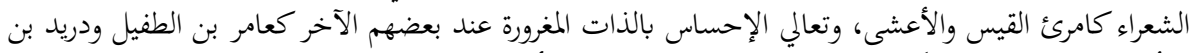

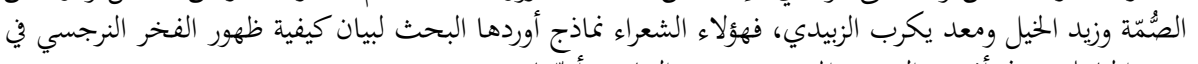

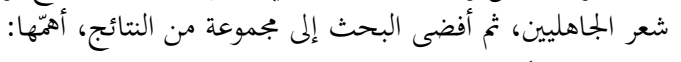

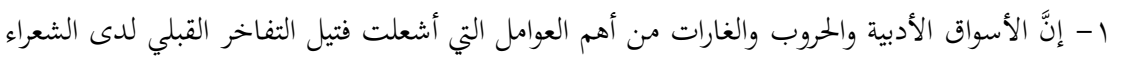

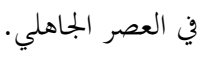

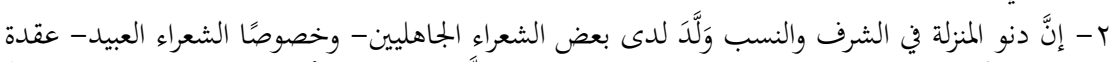

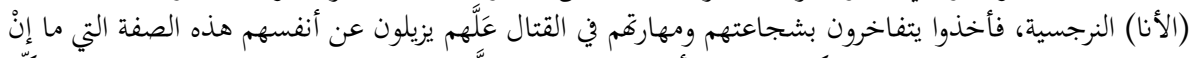

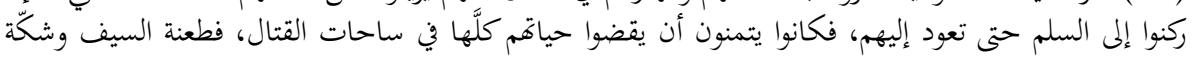

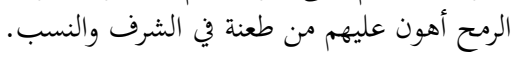

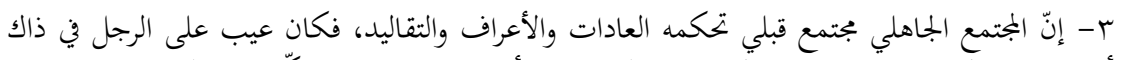

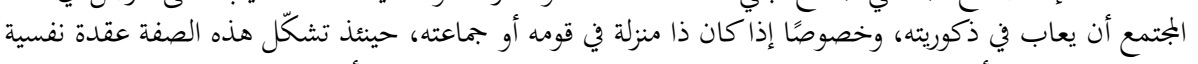

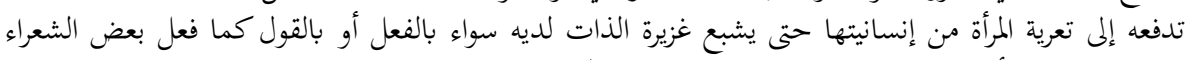

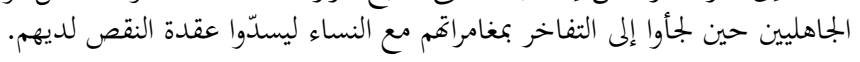

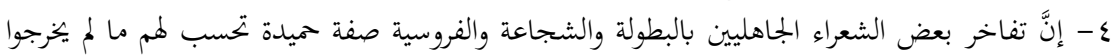

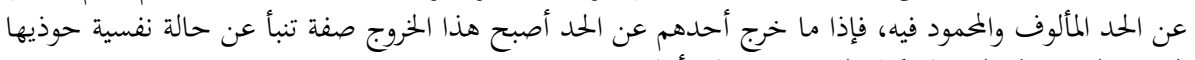

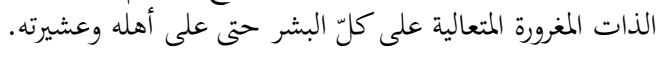




\section{KAYNAKÇA}

Abdülmelik b. Kureyb el-Asmaî. Fuhûletü'ş-şu'arâ'. Beyrut: Dârü'l-Kitâbi'l-Cedîd, 1980.

Absî, Urve b. el-Verd. ed-Dîvân. thk. Esma Ebû Bekr Muhammed. Beyrut: Dârü'lKütübi'l-İlmiyye, 1992.

A'şâ, Meymûn b. Kays. ed-Dîvân. Beyrut: Dârü'l-Kalem, 1993.

Bağdâdî, Abdülkadir b. Ömer. Hizânetü'l-edeb ve lübbü lübâbi lisani'l-Arab, thk. Abdüsselam Muhammed Hârun. Kahire: Mektebetü'l-Hâncî, 1997.

Bakkâr, Yusuf. İtticâhât fi'l-gazeli fi'l-karni's-sânîll-hicrî. Beyrut: Dârü'l-Endelüs, 1986.

Bedevi, Abde. eș-Şu'arâu's-sûd ve hasâisuhum fi'ş-ş'iri'l-arabî. Kahire: el-Hey'etü'lMısriyyetü'l-'Âmme li'l-Kitâb, 1988.

Cüde, Âmel. "en-Nercisiyye ve 'alâkatuhâ bi'l-asabiyye ledâ 'ayyine min talebeti câmiati el-aksâ". Gazze: Mecelletu Câmi'ati'l-İslâmiyyeti li'd-Dirâsâti't-Terbeviyyeti ve'n-Nefsiyye, 2/20, 2012.

David Matsumoto, The Cambridge Dictionary of psychology (New york, Cambridge university press, 2009.

Ensârî, Hassân b. Sâbit. ed-Dîvân. Beyrut: Dârü'l-Kütübi'l-İlmiyye, 1994.

Halîf, Yusuf. Dirâsât fi'ş-ş'iri'l-Cahîlî. Kahire: Dâru Garîb, 1981.

İbn Kuteybe, Abdullāh b. Müslim. eş-Şi'r ve'ş-şu'arâ. thk. Ahmet Muhammed Şakir. Kahire: Dârü'l-Ma'ârif, 1982.

İbn Reşîk, Ebû Alî el-Hasen b. Reşîk el-Ezdî el-Mesîlî el-Kayrevânî. el-'Umde fî mehâsini'ş-şi'r ve âdâbih. thk. Muhammed Muhyiddîn Abdulhamid. Beyrut: Dârü'l-Cîl, 1981.

İbnü'l-Esîr, Necmeddîn Ahmed b. İsmâîl el-Halebî. Cevherü'l-kenz. thk. Muhammed Seyîd Osman. Beyrut: Dârü'l-Kütübi'l-İlmiyye, 2012.

İmruülkays b. Hucr. ed-Dîvân. thk. Muhammad Ebü'l-Fazl İbrahim. Kahire: Dârü'lMa'ârif, 1984.

İsa, Hasan Ahmed. el-İbdâ'u fi'l-fenni ve'l-İlm. Kuveyt: el-Meclisü'l-Vatanî li'l-Lugât ve'l-Funûn ve'l-Âdâb, 1979.

İsfahanî, Ali b. Hüseyin b. Muhammed Ebü'l-Ferec. Kitabu'l-eğânî. Kahire: Dârü'lKütübi'l-Misriyye, 1369/1950.

Mekkî, et-Tahir Ahmed. Imrü̈'l-kays hayâtuhû ve şi'ruhû. Kahire: Dârü'l-Ma'ârif, 1995.

Mühelhil, Adî b. Rebîa. ed-Dîvân. Kahire: ed-Dârü'l-'Âlemiyye, ts.

Nebevî, Abdulaziz. Dîvân Benî Bakır. Kahire: Dârü'z-Zehra, 1989.

Nebevî, Abdulaziz. el-Mer'etu fî şi'ri'l-A'şâ. Kahire: Dârü's-Sadr, 1987.

Robert Michael Bagby, And others, Dsm-Iv personality disorders and the five-factor model of personality: Amulti-method examination of domain and facet-level predictions. USA: Eurpean Journal of Personality, 19/4, 2005.

Rûmiyye, Vehb. Kasîdetü'l-medh hattâ nihâyeti'l-asri'l-Emevî beyne'l-usûl ve'l-ihyâi ve't-tecdîd. Dımașk: Vizaretü's-Sekâfe, 1981.

Sakûr, Mâlik. Beyne'n-nercisiyye ve'l-gurûr ve veremi'l-ene. Dımaşk: Mecelletü'lMevkifi'l-Edebî, 2015.

Sigmund Freud, Mâ fevka mebdei'l-lezze, çev. İshak Ramzi, Kahire: Dârü'l-Maarif, 1966.

Summe, Düreyd. ed-Dîvân. thk. Ömer Abdurresûl. Kahire: Dârü'l-Ma'ârif, 1980.

Suyûfî, 'İsâm. el-Mer'et fi't-turâsi'l-arabî fi'l-edebi'l-câhilî. Beyrut: Dârü'l-Fikr, 1991.

Şenferâ, Sâbit b. Mâlik. ed-Dîvân. Beyrut: Dârül-Kitabi'l-Arabî, 1996.

Tağlibî, Amr b. Külsûm. ed-Dîvân. Beyrut: Dârül-Kitabi'l-Arabî, 1991. 
Tufeyl, Âmir. ed-Dîvân. Beyrut: Dâru Sadır, 1979.

Tuleymât, Gâzî vd. el-Edebü'l-câhilî (Kadâyâ-ağrâda-A'lâme-funûne). Beyrut: Dârü'lFikr, ts.

Tuncî, Muhammed. el-Mu'cemü'l-mufassal fi'l-edeb. Beyrut: Dârü'l-Kütübi'l-İlmiyye, 1992.

Zeydü'l-Hayl, Zeyd b. el-Mühelhil. ed-Dîvân. Bağdat: Dâru'n-Nu'man, 1968.

Zübeydî, Amr b. Ma'dikerib. ed-Dîvân. Riyad: Matbaatü'l-Abîkân, 1994. 